\title{
Penilaian Pendidikan Jasmani, Olahraga, dan Kesehatan pada Sekolah Menengah Pertama Negeri Kota Malang
}

\author{
Pinton Setya Mustafa ${ }^{1}$, M. E. Winarno ${ }^{1}$, Supriyadi ${ }^{1}$ \\ ${ }^{1}$ Pendidikan Olahraga-Universitas Negeri Malang
}

\begin{tabular}{l} 
INFO ARTIKEL \\
\hline Riwayat Artikel: \\
Diterima: 10-05-2019 \\
Disetujui: $21-10-2019$ \\
\hline
\end{tabular}

\section{Kata kunci:}

evaluation;

assessment;

physical education sports and

health;

evaluasi;

penilaian;

pendidikan jasmani olahraga dan

kesehatan

\begin{abstract}
ABSTRAK
Abstract: The purpose of this study was to evaluate the implementation of the assessment of knowledge and skills PESH in Junior High School Malang City. This study uses an evaluation approach using the model discrepancy. The results of this study on the implementation of the assessment of knowledge and skills can be said to be good. This is because the assessment document is not necessarily the same as the material in the Lesson Plan. Recommendations for the assessment of knowledge should the knowledge assessment rubric be arranged clearly, practically, qualifying questions with a high level of thinking and varied. Recommendations for skills assessment should be clear assessment rubrics, according to student characteristics, practical, and varied.

Abstrak: Tujuan penelitian ini adalah mengevaluasi pelaksanaan penilaian pengetahuan dan keterampilan PJOK pada Sekolah Menengah Pertama Negeri Kota Malang. Penelitian ini menggunakan pendekatan evaluasi dengan menggunakan discrepancy model. Hasil penelitian ini pada pelaksanaan penilaian pengetahuan dan keterampilan dapat dikatakan baik. Akan tetapi, dokumen penilaian belum tentu sama dengan materi pada Rencana Pelaksanaan Pembelajaran. Rekomendasi untu penilaian pengetahuan sebaiknya rubrik penilaian pengetahuan disusun dengan jelas, praktis, soal berkualifikasi berlevel kognitif tinggi dan bervariasi. Rekomendasi untuk penilaian keterampilan sebaiknya rubrik penilaian jelas, sesuai karakteristik siswa, praktis, dan bervariasi.
\end{abstract}

\author{
Alamat Korespondensi: \\ Pinton Setya Mustafa \\ Pendidikan Olahraga \\ Universitas Negeri Malang \\ Jalan Semarang 5 Malang \\ E-mail: pintonsetyamustafa@gmail.com
}

Pendidikan merupakan investasi masa depan bangsa dalam mewujudkan pembangunan nasional. Sebab dengan adanya kualitas pendidikan yang baik maka sumber daya manusia yang dihasilkan di masa mendatang menjadi baik juga. Dalam mewujudkan tujuan pendidikan maka diperlukan sebuah rancangan pendidikan yaitu diwujudkan dengan kurikulum yang ditetapkan oleh pemerintah. Mata pelajaran Pendidikan Jasmani, Olahraga, dan Kesehatan diwajibkan di dalam kurikulum Pendidikan Dasar dan Menengah. Pada PJOK, pendidikan diajarkan melalui aktivitas jasmani untuk mencapai tujuan pendidikan agar setiap individu dapat berkembang baik intelektual, fisik, mental, dan emosionalnya (Dwiyogo, 2010). Dengan demikian, dapat dikatakan bahwa PJOK memiliki peran penting dalam mewujudkan tujuan pendidikan.

Pendidikan Jasmani, Olahraga, dan Kesehatan di sekolah merupakan bagian penting dalam sistem pendidikan akademis yang membantu bangsa untuk mencapai tujuan dari abad ke 21 yaitu pengembangan holistik bagi peserta didik (YliPiipari, 2014). PJOK memberikan kesempatan peserta didik untuk mempelajari berbagai kegiatan untuk mengembangkan potensi mereka dalam aspek fisik, mental, sosial, emosional, dan moral (Paturusi, 2012). Tujuan PJOK untuk meningkatkan kebugaran jasmani, mengembangkan keterampilan motorik, pengetahuan, dan perilaku hidup sehat dan aktif, sikap sportif, dan kecerdasan emosi (Kanca, 2017). Pendidikan jasmani sebagai agen ekspresi diri yang dilakukan melalui aktivitas gerak untuk mencapai tujuan pendidikan yang diterapkan dalam pembelajaran yang dimodifikasi (Reid, 2013). Jadi, pembelajaran PJOK di satuan pendidikan perlu dilakukan dengan baik di bawah bimbingan guru mata pelajaran tersebut.

Dalam tahun pelajaran 2013/2014 merupakan awal tahun pergantian Kurikulum Tingkat Satuan Pendidikan ke Kurikulum 2013 yang dilakukan secara bertahap. Tahun ini merupakan tahun kelima semenjak diluncurkan kurikulum 2013 tersebut, tentunya implementasi dalam pelaksanaan kurikulum 2013 dalam satuan pendidikan lebih merata. Perubahan standarisasi kurikulum 2013, meliputi (1) standar kompetensi lulusan, (2) standar isi, (3) standar proses, dan (4) standar penilaian. Dengan demikian, dalam aspek penilaian tentunya juga harus memenuhi harapan sesuai dengan yang diharapkan dalam Kurikulum 2013. Perubahan kurikulum tersebut dilakukan karena tuntutan zaman yang semakin kompleks agar manusia indonesia dapat produktif di masa mendatang. (Dwiyogo, 2016) menyatakan bahwa diperlukan kemampuan untuk berpikir kreatif dalam menghadapi berbagai persoalan hidup. Berpikir kreatif merupakan salah satu tujuan dari kurikulum 2013. 
Penilaian pada kurikulum 2013, meliputi penilaian sikap, pengetahuan, dan keterampilan. Sebenarnya hal tersebut selaras dengan tujuan dari ranah Pendidikan Jasmani, namun dalam kebijakan kurikulum 2013 mata pelajaran PJOK penilaian yang dilakukan hanya aspek pengetahuan dan keterampilan karena penilaian sikap dilakukan oleh mata pelajaran Pendidikan Agama dan Budi Pekerti (PABP) dan Pendidikan Pancasila dan Kewarganegaraan (PPKn) (Tim Direktorat Pembinaan SMP, 2017). Jadi, kegiatan pembelajaran PJOK tidak dapat terlepas dari kegiatan evaluasi hasil belajar. Evaluasi sebagai alat yang sistematis dan analisis berbasis bukti mengenai hasil program untuk membuat keputusan yang relevan dan membuat alternatif untuk untuk mencapai hasil yang maksimal (Poth, Lamarche, Yapp, Sulla, \& Chisamore, 2014). Dengan demikian, dapat dikatakan bahwa evaluasi merupakan bagian yang harus dilakukan oleh seorang pendidik untuk meningkatkan kualitas pendidikan dan pembelajaran.

Penilaian autentik (authentic assessment) adalah ciri khas dalam penilaian Kurikulum 2013, yaitu merupakan metode penilaian yang mampu menggambarkan kemampuan sebenarnya dari peserta didik melalui penilaian terpadu antara proses pembelajaran dan hasil belajar peserta didik secara menyeluruh mencakup aspek sikap, pengetahuan, dan keterampilan. Penilaian hasil belajar siswa pada pembelajaran pendidikan jasmani mengacu pada penilaian proses dan penilaian produk (hasil belajar) (Komarudin, 2016). Penilaian pembelajaran PJOK lebih ditekankan pada penilaian proses, namun penilaian hasil juga perlu diperhatikan (Suherman, 2014). Dalam PJOK penilaian pembelajaran merupakan bagian penting dari proses belajarmengajar dan harus digunakan, dapat berupa penilaian diri, penilaian sejawat, penilaian pengamatan dari guru, portofolio, atau diskusi guru dan peserta didik (Chng \& Lund, 2018). Penilaian PJOK memiliki peran penting dalam proses pembelajaran bahkan dapat digunakan untuk pertimbangan kenaikan kelas (Borghouts, Slingerland, \& Haerens, 2017).

Penerapan penilaian hasil pembelajaran dalam implementasi Kurikulum 2013 menggunakan teknik, mekanisme, dan prosedur penilaian dengan data kuantitatif dan kualitatif di rapor. Ketika awal pelaksanaan penilaian dalam kurikulum 2013, 87\% guru mengalami kesulitan tentang cara penilaiannya (UNNES, 2013). Selain itu, penilaian dalam kurikulum 2013 membuat guru pusing, beban sekolah juga pada terlalu banyaknya mata pelajaran sehingga guru tidak fokus mengajar (Rahmat, 2014). Berdasarkan hasil penelitian yang dilakukan oleh (Kastina \& Sujianto, 2017) menyimpulkan bahwa implementasi sistem penilaian dalam kurikulum 2013 di SMA Negeri 2 Pekanbaru belum dapat diterapkan dengan baik dan optimal, dikarenakan (1) sumber daya manusia yang belum memadai, (2) masih kurangnya koordinasi antara pelaksana, sasaran kebijakan, serta pemerintah pusat, dan (3) skala penilaian pada rapor yang selalu mengalami perubahan secara mendadak. Berangkat dari isu tersebut, maka perlu dilakukan penelusuran lebih dalam tentang pelaksanaan penilaian kurikulum 2013 pada pelajaran PJOK.

Adapun data hasil penelitian terdahulu mengenai penilaian dalam PJOK kurikulum 2013, antara lain (1) rubrik penilaian keterampilan yang dikembangkan oleh guru, setiap indikator belum dapat mengukur kemampuan yang tinggi dan rendah bagi siswa (Fathoni, 2017), (2) guru kurang memahami menganalisis butir instrumen penilaian kognitif, belum memahami instrumen penilaian yang baik, instrumen penilaian yang digunakan setiap tahun sama (Aji \& Winarno, 2016), (3) instrumen soal pengetahuan belum memenuhi kategori instrumen tes yang baik karena belum memenuhi validitas, reliabilitas, objektif, praktikabilitas, tingkat kesukaran soal masih belum memenuhi standar (Juniarta \& Winarno, 2016), (4) soal pengetahuan belum memenuhi kriteria instrumen tes yang baik dari segi validitas, reliabilitas, tingkat kesukaran, dan penerapan level kognitif yang tinggi (Ardyanto, Winarno, \& Adi, 2016). Penelitian evaluasi yang telah dilakukan oleh (Darmawan, 2018) tentang pembelajaran PJOK di SMP/MTs kecamatan Trenggalek yaitu pada aspek penilaian diperoleh hasil bahwa penilaian yang dilakukan oleh guru dalam pembelajaran PJOK belum memenuhi standar, yaitu dengan persentase 62,92\% berkategori "cukup baik". Selanjutnya, penelitian evaluasi pembelajaran PJOK yang dilakukan oleh (Dhuhary, 2018) bahwa komponen penilaian pada mata pelajaran PJOK di SMP/MTs pada Yayasan An-Nur Kecamatan Bululawang Kabupaten Malang memperoleh persentase 45,31\% termasuk dalam kategori "kurang baik".

Sebagaimana pada kurikulum 2013 yang telah ditetapkan oleh pemerintah, maka kurikulum 2013 diimplementasikan mulai dari bulan Juli tahun 2013 di setiap satuan pendidikan di Indonesia. Sampai saat ini sudah 6.221 sekolah dari jumlah total seluruh sekolah di seluruh Indonesia yaitu 208.000 sekolah (SD/SMP/SMA/SMK) yang terdiri dari 2.598 SD, 1.473 SMP, 1.165 SMA, dan 1.021 SMK yang tersebar di 295 kabupaten dan kota di seluruh Indonesia menerapkan kurikulum 2013 (Kastina \& Sujianto, 2017). Kurikulum 2013 terus mengalami revisi agar lebih mudah dan praktis dijalankan. Beberapa sekolah yang menerapkan Kurikulum 2013 revisi 2016 adalah SMP Negeri 2, 4, 6 Malang.

Ketiga sampel SMP Negeri Malang di atas merupakan sekolah dengan akreditasi A di kota Malang yang menerapkan kurikulum 2013. Berdasarkan observasi awal yang dilakukan mulai tanggal 10 September-15 Oktober 2018 dengan memberikan angket kepada sembilan guru PJOK di SMPN 2, 4, dan 6 Malang diperoleh data sebagai berikut. Pertama, dalam penyusunan RPP, enam guru menyatakan menyusun RPP sendiri dan tiga guru memperoleh RPP yang disusun oleh MGMP. Kedua, untuk tujuan pembelajaran PJOK yang ingin dicapai oleh guru, yaitu enam guru ingin mencapai ranah sikap, delapan guru ingin mencapai ranah pengetahuan, dan sembilan guru ingin mencapai ranah keterampilan. Ketiga, rubrik penilaian yang telah disiapkan oleh sembilan guru, yaitu tiga guru menyiapkan ranah sikap, delapan guru menyiapkan ranah pengetahuan, dan sembilan guru menyiapkan ranah keterampilan. Keempat, seorang guru berargumen bahwa selama ini belum mengetahui format RPP yang benar dan baku dikarenakan setiap pelatihan dan RPP dari tiap sekolah memiliki idealis sendiri-sendiri. 
Kelima, seorang guru menyatakan bahwa untuk saat ini penilaian sikap menggunakan jurnal harian karena kebijakan kurikulum 2013 revisi, sehingga sudah tidak menggunakan lagi rubrik penilaian sikap, sebab standar penilaian mengalami revisi sebab guru-guru mata pelajaran mengalami kesulitan jika menilai sikap, sehingga penilaian sikap hanya dilakukan oleh PABP dan PPKn. Keenam, berdasarkan analisis dokumentasi dari silabus dan RPP diperoleh data bahwa lima guru menuliskan 10 KD (pengetahuan dan keterampilan) di silabusnya padahal dari silabus tersebut belum tentu dilakukan untuk pengembangan RPP.

Berdasarkan data awal di atas dapat disimpulkan bahwa dari setiap karakteristik guru PJOK memiliki persepsi yang berbeda dalam merencanakan dan melakukan penilaian dikarenakan kondisi sekolah yang bervariasi. Kemudian apakah dengan adanya perbedaan persepsi, penilaian PJOK tetap mencerminkan KD dengan benar maka diperlukan sebuah penelitian. Penelitian yang dilakukan adalah evaluasi pada komponen penilaian pembelajaran PJOK dalam aspek penilaian pengetahuan dan keterampilan. Pada kurikulum 2013 revisi 2016 mata pelajaran PJOK tidak menilai sikap dengan dominan. Tujuan penilaian pengetahuan untuk mengukur tingkat penguasaan kompetensi peserta didik dalam aspek pengetahuan (Komarudin, 2016). Dari penilaian pengetahuan tersebut memiliki level kognitif berdasarkan Taksonomi Bloom Revisi, yaitu sebagai berikut: (1) mengingat (C1), (2) memahami (C2), (3) menerapkan (C3), (4) menganalisis (C4), (5) mengevaluasi (C5), dan (6) mengkreasi (C6) (Farida, 2017). Sedangkan penilaian keterampilan adalah proses pengumpulan informasi untuk mengukur proses dan hasil pencapaian kemampuan peserta didik dalam aspek bertindak atau gerak (psikomotor) (Winarno, 2014). Pada penilaian keterampilan dikategorikan dengan Taksonomi Dave, meliputi (1) imitasi (P1), (2) manipulasi (P2), (3) presisi (P3), (4) artikulasi (P4), dan (5) naturalisasi (P5) (Kunandar, 2013). Sebuah instrumen penilaian yang baik harus memenuhi kriteria valid, reliabel, objektif, beracuan norma, praktis, dan memiliki petunjuk pelaksanaan yang jelas (Winarno, 2014). Dengan demikian, diperlukan penelitian evaluasi tentang pelaksanaan penilaian PJOK terutama mengenai kualitas instrumen penilaian yang digunakan selama pembelajaran.

Evaluasi secara umum merupakan proses yang menentukan kondisi dimana suatu tujuan harus dicapai (Sukardi, 2011). Dengan demikian untuk mengetahui sejauh mana pencapaian tujuan pendidikan nasional dengan kondisi pendidikan maupun pembelajaran di lapangan maka perlu dilakukan evaluasi. Dalam ilmu evaluasi terdapat berbagai model yang dapat digunakan dalam mengevaluasi program. Model evaluasi merupakan desain evaluasi sesuai dengan misi dan kepentingan yang inginkan serta ada yang menyesuaikan dengan paham yang dianut (Widoyoko, 2013). Discrepancy model, yaitu model evaluasi yang bertujuan menentukan perbedaan apa yang ada dengan suatu standar serta untuk mengetahui apakah ada selisih (Supriyono, 2013). Penggunaan model evaluasi program dapat dipilih agar efektif dan berperan sangat penting bagi kelanjutan peningkatan mutu pendidikan dan pembelajaran (Zhang et al., 2011). Dapat dikatakan model evaluasi tersebut tepat digunakan dalam bidang pendidikan dan pembelajaran.

Berdasarkan uraian permasalahan di atas maka perlu dilakukan penelitian tentang pelaksanaan penilaian PJOK. Namun penelitian ini hanya dilakukan pada jenjang SMP yang berada di Kota Malang. Tujuan penelitian ini untuk mengevaluasi (1) pelaksanaan penilaian pengetahuan dan (2) pelaksanaan penilaian keterampilan pada mata pelajaran PJOK yang diselenggarakan oleh SMP Negeri Kota Malang. Setelah kegiatan evaluasi, didapatkan data informasi tentang kualitas pelaksanaan penilaian PJOK. Data tersebut dapat digunakan untuk membuat atau menetapkan kebijakan terhadap pelaksanaan penilaian PJOK yang lebih baik.

\section{METODE}

Penelitian ini termasuk penelitian evaluasi dengan discrepancy model yang bertujuan untuk mengevaluasi pelaksanaan penilaian PJOK kurikulum 2013 pada SMP Negeri di kota Malang. Model discrepancy (kesenjangan) adalah untuk mengetahui tingkat kesesuaian antara standar yang sudah ditentukan dengan kinerja di lapangan (Muryadi, 2017). Jadi evaluasi ini dilakukan bertujuan untuk mengetahui tingkat kesenjangan dari pelaksanaan penilaian PJOK dengan standar yang ditetapkan pada kurikulum 2013. Hasil dari evaluasi ini dapat digunakan untuk pengambilan keputusan dengan memberikan rekomendasi pada pelaksanaan penilaian PJOK di SMP Negeri Kota Malang.

Prosedur penelitian evaluasi model discrepancy ini terdiri dari (1) tahap penyusunan desain dengan menentukan kriteria evaluasi diperlukan merumuskan tujuan, menyiapkan audiens, personil, dan kelengkapan instrumen, dan menentukan kriteria pada sesuatu yang dapat diukur; (2) tahap pemasangan instalasi adalah pembuatan instrumen evaluasi untuk menilai tingkat kesenjangan dalam pelaksanaan penilaian; (3) tahap proses adalah pengumpulan data penelitian evaluasi yaitu dari RPP, rancangan penilaian, serta persepsi guru dan siswa; (4) tahap pengukuran tujuan yaitu mengadakan analisis data dan menetapkan tingkat kesenjangan yang diperoleh. Tahap terakhir adalah pembandingan yaitu membandingkan hasil analisis data dengan kriteria yang telah ditetapkan. Selanjutnya, pengambilan keputusan terhadap kesenjangan yang terjadi dalam pelaksanaan penilaian PJOK kurikulum 2013 di SMP Negeri kota Malang.

Teknik pengambilan sampel dilakukan dengan menggunakan teknik sampling purposive, yaitu pengambilan sampel dilakukan atas dasar pertimbangan penelitian untuk mencapai tujuan tertentu (Winarno, 2013), yaitu sebanyak sembilan SMP Negeri di Kota Malang. Adapun rinciannya adalah enam SMP yang dapat mewakili lima kecamatan dan tiga SMP yang dapat mewakili sekolah yang memiliki sertifikat International Organization of Standardization (ISO) 9001:2008. ISO 9001:2008 merupakan standar yang mengatur tentang sistem manajemen mutu yang diakui internasional dan arti dari 2008 adalah menunjukkan hasil revisi tahun 2008 (Larasati, Hanafi, \& Hayat, 2013). 
Subjek dalam penelitian ini adalah guru PJOK dan peserta didik yang diajar oleh guru tersebut. Pemilihan sampel pada subjek pada guru dan peserta didik menggunakan teknik purposive yaitu guru kelas VII dan VIII yang mengajar di sekolah serta peserta didik yang diajar oleh guru tersebut. Pada kelas IX tidak dijadikan sampel penelitian karena kelas IX diprogram oleh sekolah untuk fokus menghadapi ujian nasional sehingga data kelas IX tidak dimungkinkan untuk diambil. Penelitian ini dimulai pada tanggal 14 Januari-19 Maret 2019. Penelitian ini dilaksanakan di sembilan SMP Negeri di kota Malang, yaitu (1) SMPN 4 Malang, (2) SMPN 2 Malang, (3) SMPN 6 Malang, (4) SMPN 20 Malang, (5) SMPN 17 Malang, (6) SMPN 10 Malang, (7) SMPN 1 Malang, (8) SMPN 3 Malang, dan (9) SMPN 5 Malang.

Instrumen yang digunakan untuk mengumpulkan data, meliputi (1) dokumentasi, (2) wawancara, dan (3) angket. Penyusunan instrumen diawali dengan pembuatan kisi-kisi kemudian disusun butir pertanyaan yang berkaitan dengan penelitian. Pembuatan instrumen berdasarkan standar kurikulum 2013 revisi 2016 dan konsep pendidikan jasmani. Instrumen dokumentasi digunakan untuk mengumpulkan data berkaitan dengan instrumen penilaian formatif-sumatif pada aspek pengetahuan dan keterampilan yang digunakan dalam pelajaran PJOK dari instrumen penilaian di RPP dan dokumen nilai guru menggunakan checklist kemudian dicross-check. Wawancara digunakan untuk menggali informasi lebih mendalam tentang pelaksanaan penilaian dari guru PJOK. Angket digunakan untuk mengumpulkan data tambahan tentang penilaian PJOK.

Pengumpulan data dalam penelitian ini terdiri dari pengumpulan data kuantitatif dan kualitatif. Data kuantitatif diperoleh dari skor telaah dokumentasi dan angket dari siswa. Data kualitatif diperoleh dari hasil wawancara kepada guru PJOK. Tahap-tahap dalam pengumpulan data, meliputi tahap persiapan, tahap pelaksanaan, dan tahap pelaporan.

Teknik analisis data yang digunakan yaitu teknik analisis kualitatif dan kuantitatif. Analisis kualitatif digunakan untuk menganalisis hasil pengumpulan data dari wawancara terhadap guru PJOK atau data berupa kalimat. Teknik analisis data kualitatif dilakukan melalui tahap (1) data reduction, (2) data display, dan (3) conclusion drawing/verification (Sugiyono, 2015). Teknik analisis data kuantitatif yang digunakan adalah analisis deskriptif persentase untuk data yang diperoleh dari hasil telaah dokumen dan angket yang menggunakan rumus dari (Sudijono, 2008) berikut.

\section{Keterangan:}

$$
\mathrm{P}=\frac{f}{\mathrm{~N}} \times 100 \%
$$

$f=$ Jumlah frekuensi atau skor yang didapat

$\mathrm{N}=$ Jumlah keseluruhan sampel atau skor maksimal

$\mathrm{P}=$ Angka persentase (\%)

Hasil dari analisis data kuantitatif kemudian dikategorikan dengan menggunakan kriteria penggolongan persentase yang telah ditetapkan oleh (Arikunto \& Jabar, 2009) untuk mengetahui kategori dari variabel dan indikator penilaian pengetahuan dan keterampilan. Adapun kategorisasi kriteria analisis persentase dapat dilihat pada tabel 1.

Tabel 1. Kriteria Kategorisasi Analisis Persentase

\begin{tabular}{ccl}
\hline No & Persentase $(\%)$ & \multicolumn{1}{c}{ Kategori } \\
\hline 1. & $80-100$ & Sangat Baik \\
2. & $66-79$ & Baik \\
3. & $56-65$ & Cukup Baik \\
4. & $40-55$ & Kurang Baik \\
5. & $<40$ & Tidak Baik \\
\hline
\end{tabular}

(Sumber: Arikunto \& Jabar, 2009)

\section{HASIL}

Penelitian pelaksanaan penilaian PJOK yang telah dilakukan mulai tanggal 14 Januari-19 Maret 2019 dengan sampel sebanyak 18 guru PJOK dari sembilan SMP Negeri kota Malang, yakni SMPN 1, SMPN 2, SMPN 3, SMPN 4, SMPN 5, SMPN 6, SMPN 10, SMPN 17, dan SMPN 20. Tujuan penelitian ini memotret dan mengevaluasi pelaksanaan penilaian pengetahuan (KI 3) dan penilaian keterampilan (KI 4) selama semester I. Dalam kurikulum 2013 revisi 2016, penilaian sikap spiritual (KI 1) dan sikap sosial (KI 2) tidak menjadi variabel penelitian, sebab yang menilai sikap secara dominan adalah guru mata pelajaran BK, PPkn, dan PABP. Oleh karena itu, sajian data penelitian ini hanya fokus pada penilaian pengetahuan dan keterampilan.

Adapun pengisian angket dari 18 guru PJOK SMP Negeri di kota Malang diperoleh data sebagai berikut. Pertama, 100\% guru menggunakan kurikulum 2013 sebagai acuan pembelajaran PJOK. Kedua, 61,11\% guru menggunakan silabus dari Kemendikbud, 27,78\% guru menyusun silabus sendiri dan 38,89\% guru menggunakan silabus dari MGMP. Ketiga, 83,33\% guru menggunakan RPP yang disusun oleh MGMP dan 55,56\% menyusun RPP secara mandiri. Selain itu, ada yang membuat RPP berdasarkan MGMP Sekolah. Keempat, 100\% guru menggunakan tes tulis, 33,33\% guru menggunakan tes lisan, dan $72,22 \%$ guru menggunakan penugasan (penilaian pengetahuan). Kelima, 94,44\% guru menggunakan tes praktik pendekatan 
proses, 66,67\% guru menggunakan tes praktik pendekatan produk, 44,44\% guru menggunakan penilaian proyek, 33,33\% guru menggunakan penilaian portofolio (penilaian keterampilan). Berdasarkan dari penyebaran angket dapat disimpulkan bahwa semua guru menyusun RPP dan melakukan penilaian pengetahuan dan keterampilan selama semester I tahun pelajaran $2018 / 2019$.

Berikut ini adalah hasil analisis data menggunakan studi dokumen dari isi materi PJOK yang ada pada RPP semester I terhadap Kompetensi Dasar pada aspek pengetahuan dan keterampilan dari sampel sembilan SMP Negeri kota Malang dengan 18 guru PJOK.

Tabel 2. Analisis Data dari RPP Semester 1 PJOK SMPN Malang terhadap KD

\begin{tabular}{clccc}
\hline No & Kompetensi Dasar (KD) & N & f & \% \\
\hline 1 & $3.1-4.1$ Permainan bola besar & 18 & 18 & 100 \\
2 & $3.2-4.2$ Permainan bola kecil & 18 & 16 & 88,89 \\
3 & 3.3 -4.3 Atletik & 18 & 16 & 88,89 \\
4 & $3.4-4.4$ Beladiri & 18 & 7 & 38,89 \\
5 & $3.5-4.5$ Kebugaran jasmani & 18 & 12 & 66,67 \\
6 & 3.6 -4.6 Senam Lantai & 18 & 8 & 44,44 \\
7 & $3.7-4.7$ Gerak berirama & 18 & 7 & 38,89 \\
8 & 3.8 -4.8 Renang & 18 & 0 & 0 \\
9 & $3.9-4.9$ Perkembangan Tubuh Remaja (VII)/ & 18 & 3 & 16,67 \\
& Pencegahan Pergaulan Bebas (VIII) & 18 & 0 & 0 \\
10 & 3.10-4.10 Pola Makan Sehat (VII)/ & & & \\
& Keselamatan di Jalan Raya (VIII) & & & \\
\hline & Jumlah & $\mathbf{1 8 0}$ & $\mathbf{8 7}$ & $\mathbf{4 8 , 3 3}$ \\
\hline
\end{tabular}

\section{Keterangan:}

$\mathrm{N}=$ jumlah keseluruhan responden penelitian (18 guru); $\mathrm{f}=$ jumlah guru yang menyusun $\mathrm{RPP} ;(\%)=$ persentase

Berdasarkan hasil analisis data tabel 2 tentang data RPP selama semester I rata-rata 18 guru PJOK SMP Negeri Malang hanya menyusun $48,33 \%$ dari $10 \mathrm{KD}$ pengetahuan dan keterampilan yang ada. Pada KD yang memiliki persentase tertinggi adalah KD 3.1-4.1 permainan bola besar yaitu sebesar 100\%. Kemudian posisi tertinggi kedua adalah KD 3.2-4.2 permainan bola kecil dan KD 3.3-4.3 atletik sebesar 88,89\%. Sedangkan KD yang tidak disusun RPPnya untuk materi PJOK semester 1 adalah KD 3.8-4.8 renang dan KD 3.10-4.10 pola makan sehat untuk kelas VII serta keselamatan di jalan raya untuk kelas VIII. Berdasarkan dari RPP tersebut, merupakan acuan dan dasar peneliti untuk menelusuri sejauh mana kesesuaian keterlaksanaan penilaian PJOK dengan materi dalam RPP melalui teknik studi dokumen catatan penilaian yang dimiliki guru.

Tabel 3. Analisis Data dari RPP Semester I Materi PJOK SMP Negeri Malang

\begin{tabular}{|c|c|c|c|c|c|}
\hline KD & No & Materi & $\mathbf{N}$ & $\mathbf{f}$ & $\%$ \\
\hline \multirow[t]{3}{*}{$3.1-4.1$} & 1 & Permainan Sepakbola & 18 & 10 & 55,56 \\
\hline & 2 & Permainan Bolavoli & 18 & 18 & 100 \\
\hline & 3 & Permainan Bolabasket & 18 & 15 & 83,33 \\
\hline \multirow[t]{3}{*}{$3.2-4.2$} & 4 & Permainan Kasti / Softball & 18 & 9 & 50 \\
\hline & 5 & Permainan Bulutangkis & 18 & 12 & 66,67 \\
\hline & 6 & Permainan Tenis Meja & 18 & 0 & 0 \\
\hline \multirow[t]{6}{*}{$3.3-4.3$} & 7 & Jalan Cepat & 18 & 3 & 16,67 \\
\hline & 8 & Lari Jarak Pendek & 18 & 15 & 83,33 \\
\hline & 9 & Lompat Jauh & 18 & 3 & 16,67 \\
\hline & 10 & Lompat Tinggi & 18 & 0 & 0 \\
\hline & 11 & Tolak Peluru & 18 & 2 & 11,11 \\
\hline & 12 & Lempar Cakram & 18 & 0 & 0 \\
\hline $3.4-4.4$ & 13 & Pencaksilat & 18 & 7 & 38,89 \\
\hline $3.5-4.5$ & 14 & Kebugaran Jasmani & 18 & 12 & 66,67 \\
\hline $3.6-4.6$ & 15 & Senam Lantai & 18 & 8 & 44,44 \\
\hline $3.7-4.7$ & 16 & Aktivitas Gerak Berirama & 18 & 7 & 38,89 \\
\hline $3.8-4.8$ & 17 & Renang & 18 & 0 & 0 \\
\hline $3.9-4.9$ & 18 & Perkembangan Tubuh Remaja (VII)/ Pencegahan Pergaulan Bebas (VIII) & 18 & 3 & 16,67 \\
\hline $3.10-4.10$ & 19 & Pola Makan Sehat (VII)/ Keselamatan di Jalan Raya (VIII) & 18 & 0 & 0 \\
\hline & & Jumlah & 342 & 124 & 36,26 \\
\hline
\end{tabular}




\section{Keterangan:}

$\mathrm{N}=$ jumlah keseluruhan responden penelitian (18 guru); $\mathrm{f}=$ jumlah guru yang menyusun RPP; $(\%)=$ persentase

Berdasarkan hasil analisis data dari Tabel 3 tentang data materi RPP selama semester I rata-rata 18 guru PJOK SMP Negeri

Malang hanya menyusun 36,26\% dari keseluruhan materi yang mewakili $10 \mathrm{KD}$ pengetahuan dan keterampilan. Berikut ini adalah hasil analisis data menggunakan studi dokumen antara kesesuaian materi pada RPP semester I dengan dokumen hasil penilaian guru pada aspek pengetahuan (KI 3) dan keterampilan (KI 4) yang disajikan pada tabel 4.

Tabel 4. Analisis Data Keterlaksanaan Penilaian pada RPP Semester 1

\begin{tabular}{|c|c|c|c|c|c|c|c|}
\hline \multirow{2}{*}{ KD } & \multirow{2}{*}{ No } & \multirow{2}{*}{ Materi } & \multirow{2}{*}{ NRPP } & \multicolumn{2}{|c|}{$\begin{array}{c}\text { Dokumen } \\
\text { Penilaian K I3 }\end{array}$} & \multicolumn{2}{|c|}{ Dokumen Penilaian KI 4} \\
\hline & & & & $f_{\text {DokN }}$ & $\%$ & $f_{\text {DokN }}$ & $\%$ \\
\hline \multirow[t]{3}{*}{$3.1-4.1$} & 1 & Permainan Sepakbola & 10 & 8 & 80 & 9 & 90 \\
\hline & 2 & Permainan Bolavoli & 18 & 17 & 94,44 & 17 & 94,44 \\
\hline & 3 & Permainan Bolabasket & 15 & 13 & 86,67 & 13 & 86,67 \\
\hline \multirow[t]{2}{*}{$3.2-4.2$} & 4 & Permainan Kasti / Softball & 9 & 6 & 66,67 & 5 & 55,56 \\
\hline & 5 & Permainan Bulutangkis & 12 & 11 & 91,67 & 9 & 75 \\
\hline \multirow[t]{4}{*}{$3.3-4.3$} & 7 & Jalan Cepat & 3 & 1 & 33,33 & 1 & 33,33 \\
\hline & 8 & Lari Jarak Pendek & 15 & 13 & 86,67 & 14 & 93,33 \\
\hline & 9 & Lompat Jauh & 3 & 2 & 66,67 & 2 & 66,67 \\
\hline & 11 & Tolak Peluru & 2 & 1 & 50 & 1 & 50 \\
\hline $3.4-4.4$ & 13 & Pencaksilat & 7 & 4 & 57,14 & 4 & 57,14 \\
\hline $3.5-4.5$ & 14 & Kebugaran Jasmani & 12 & 11 & 91,67 & 11 & 91,67 \\
\hline $3.6-4.6$ & 15 & Senam Lantai & 8 & 4 & 50 & 5 & 62,5 \\
\hline $3.7-4.7$ & 16 & Aktivitas Gerak Berirama & 7 & 3 & 42,86 & 6 & 85,71 \\
\hline $3.8-4.8$ & 17 & Renang & 0 & 0 & - & 0 & - \\
\hline $3.9-4.9$ & 18 & Perkembangan Tubuh Remaja (VII)/ Pencegahan Pergaulan & 3 & 1 & 33,33 & 0 & 0 \\
\hline \multirow[t]{5}{*}{$3.10-4.10$} & 19 & Bebas (VIII) & 0 & 0 & - & 0 & - \\
\hline & & Pola Makan Sehat (VII)/ Keselamatan di Jalan Raya (VIII) & & & & & \\
\hline & & Jumlah & 124 & 95 & 76,61 & 97 & 78,23 \\
\hline & & Rerata KI 3+ K1 4 (\%) & & & & $\mathbf{7 7 , 4 2}$ & \\
\hline & & Kesenjangan (\%) & & & & 22,58 & \\
\hline
\end{tabular}

\section{Keterangan:}

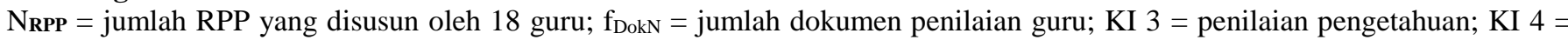
penilaian keterampilan

Berdasarkan hasil analisis data dari tabel 4 tentang keterlaksanaan penilaian pengetahuan dan keterampilan dengan KD pada materi RPP semester I yang disusun oleh guru secara keseluruhan diperoleh persentase sebesar 77,42\% dengan kategori "baik". Pada aspek penilaian pengetahuan dapat dilaksanakan sebesar 76,61\% dengan kategori "baik", sedangkan pada aspek penilaian keterampilan dapat dilaksanakan sebesar 78,23\% dengan kategori "baik".

Dengan demikian, dapat disimpulkan bahwa tidak semua materi PJOK yang direncanakan oleh guru dapat diambil datanya dalam penilaian. Hal tersebut terbukti hanya sebesar $77,42 \%$ yang dapat dilakukan, sedangkan $22,58 \%$ masih belum dapat dilakukan. Selain itu, pelaksanaan penilaian pengetahuan dan keterampilan belum berjalan secara selaras. Keterlaksanaan penilaian keterampilan memiliki persentase lebih besar daripada pengetahuan dilihat dari segi materi dalam RPP PJOK. Untuk meninjau apakah penilaian pengetahuan dan keterampilan memiliki kualitas dan prosedur yang baik, maka hasil analisis data disajikan pada subbab berikutnya.

\section{Hasil Analisis Data Pelaksanaan Penilaian Pengetahuan PJOK di SMP Negeri Malang}

Penilaian pengetahuan PJOK di SMPN Kota Malang diperoleh dari penilaian formatif dan sumatif. Penilaian formatif yaitu penilaian pengetahuan yang didapat dari penilaian harian berupa tes tulis ulangan harian, tes lisan, dan pemberian tugas. Pada ulangan harian, soal dapat berbentuk pilihan ganda dan esai biasanya yang dikenal dengan tes tulis. Pada tes lisan yaitu guru memberikan soal secara lisan kemudian siswa menjawab pertanyaan tersebut secara lisan. Dalam teknik penilaian penugasan dapat dilakukan dengan guru menyuruh siswa merangkum setiap materi pembelajaran, memberikan soal untuk mengerjakannya baik secara berkelompok maupun individu, dan mengerjakan soal di buku paket PJOK kurikulum 2013.

Berikut hasil analisis data menggunakan studi dokumen tentang kualitas kelengkapan komponen penilaian pengetahuan yang ditinjau dari: adanya petunjuk, kunci jawaban, dan pengolahan skor hasil yang disusun dalam RPP 18 guru PJOK pada semester I tahun pelajaran 2018/2019. 
Tabel 5. Analisis Data Kelengkapan Komponen Instrumen Penilaian Pengetahuan di RPP

\begin{tabular}{lllcccc}
\hline Indikator & No & Bentuk & fRPP & NSkor & fSkor & $(\%)$ \\
\hline (1) petunjuk mengerjakan & 1 & Tes pilihan ganda & 39 & 156 & 127 & 81,41 \\
(2) kunci jawaban & 2 & Tes esai & 103 & 412 & 281 & 68,2 \\
(3) pengolahan skor hasil akhir & 3 & Penugasan & 80 & 320 & 107 & 33,44 \\
& 4 & Tes lisan & - & - & - & - \\
\cline { 2 - 6 } & & Jumlah & $\mathbf{2 2 2}$ & $\mathbf{8 8 8}$ & $\mathbf{5 1 5}$ & $\mathbf{5 8}$ \\
\hline
\end{tabular}

\section{Keterangan:}

$\mathrm{f}_{\mathrm{RPP}}=$ jumlah bentuk penilaian yang ada di setiap RPP dari 18 guru; Nskor = skor maksimal; fskor = skor hasil

Berdasarkan hasil analisis data dari tabel 5 tentang kelengkapan komponen instrumen penilaian pengetahuan di RPP dengan sampel 18 guru PJOK secara keseluruhan diperoleh persentase sebesar 58\% dapat dikategorikan "cukup baik". Hal tersebut belum mencapai kategori "sangat baik" karena instrumen penilaian pengetahuan pada teknik tes tulis pilihan ganda maupun esai belum dilengkapi petunjuk mengerjakan dan kunci jawaban yang jelas. Selain itu, pada teknik penugasan belum memberikan perintah tugas dengan jelas beserta pedoman penilaiannya dengan jelas. Apabila dikelompokkan berdasarkan variasi jenis penilaian pengetahuan yang dipilih guru untuk disusun pada RPP disajikan pada tabel 6.

Tabel 6. Analisis Data Pemilihan Bentuk Penilaian Pengetahuan dari Guru PJOK dalam RPP

\begin{tabular}{lccl}
\hline Bentuk Penilaian di RPP & $\mathbf{N}_{\text {guru }}$ & $\mathbf{f}_{\text {Guru }}$ & $\mathbf{( \% )}$ \\
\hline Tes dengan pilihan ganda & 18 & 10 & 55,56 \\
Tes dengan esai & 18 & 17 & 94,44 \\
Penugasan & 18 & 12 & 66,67 \\
Tes lisan & 18 & - & - \\
\hline
\end{tabular}

\section{Keterangan:}

$\mathrm{N}_{\text {Guru }}=$ Jumlah keseluruhan responden (18 guru); $\mathrm{f}_{\mathrm{Guru}}=$ Jumlah pemilihan bentuk penilaian oleh guru; $(\%)=$ persentase

Berdasarkan Tabel 6 guru cenderung menyusun instrumen penilaian pengetahuan di RPP dalam bentuk tes menggunakan esai yaitu sebesar 94,44\%. Secara keseluruhan, kelengkapan komponen pada tes esai tersebut hanya mendapatkan skor $68,2 \%$ dengan kategori "baik". Hal tersebut dikarenakan pada tes esai guru cenderung tidak menyajikan kunci jawabannya. Berbeda jika guru menggunakan tes dengan pilihan ganda, yaitu pada tabel 5 rata-rata kelengkapan komponennya sebesar $81,41 \%$ dengan kategori "sangat baik".

Dengan demikian, dapat disimpulkan bahwa rancangan penilaian pengetahuan di RPP belum mencerminkan kualitas kelengkapan yang sangat baik. Hal tersebut dikarenakan belum lengkapnya petunjuk mengerjakan dan kunci jawaban yang jelas. Setelah menganalisis kelengkapan komponen penilaian pengetahuan selanjutnya peneliti menganalisis pengelompokan soal yang ada di RPP terhadap level kognitifnya pada Taksonomi Bloom revisi. Berikut ini adalah hasil analisis data menggunakan studi dokumen tentang pengelompokan jenis soal yang ada di RPP terhadap level kognitif Taksonomi Bloom revisi.

Tabel 7. Hasil Analisis Data Soal di RPP PJOK SMPN Malang terhadap Level Kognitif

\begin{tabular}{|c|c|c|c|c|c|c|c|c|c|c|c|c|}
\hline \multirow{2}{*}{$\underset{\text { Soal }}{\sum N}$} & \multicolumn{2}{|c|}{ Mengingat (C1) } & \multicolumn{2}{|c|}{ Memahami (C2) } & \multicolumn{2}{|c|}{ Menerapkan (C3) } & \multicolumn{2}{|c|}{ Menganalisis (C4) } & \multicolumn{2}{|c|}{ Mengevaluasi (C5) } & \multicolumn{2}{|c|}{ Mengkreasi (C6) } \\
\hline & $\sum \mathbf{f}$ & $(\%)$ & $\sum \mathbf{f}$ & $(\%)$ & $\sum \mathbf{f}$ & $(\%)$ & $\sum \mathbf{f}$ & $(\%)$ & $\sum \mathbf{f}$ & $(\%)$ & $\sum \mathbf{f}$ & $(\%)$ \\
\hline 521 & 48 & 9,21 & 307 & 58,93 & 169 & 32,44 & 0 & 0 & 0 & 0 & 0 & 0 \\
\hline
\end{tabular}

\section{Keterangan:}

$\sum \mathrm{N}=$ jumlah keseluruhan butir soal di semua RPP yang dibuat 18 guru; $\sum \mathrm{f}=$ jumlah soal dengan tingkat kognitif taksonomi bloom revisi; $(\%)=$ persentase

Berdasarkan tabel 7 dapat disimpulkan bahwa dari 18 guru di semua RPPnya soal untuk instrumen penilaian masih belum mencapai level kognitif yang tinggi atau Higher Orders Thinking Skills (HOTS). Hal tersebut terbukti karena didominasi oleh level kognitif memahami (C2) yaitu sebesar 58,93\% kemudian level kognitif menerapkan sebesar (C3) 32,44\%, dan level kognitif mengingat (C1) sebesar 9,21\%. Belum ada soal pada RPP yang mencapai level kognitif menganalisis (C4), mengevaluasi (C5), dan mengkreasi (C6).

Setelah menganalisis kualitas instrumen penilaian pengetahuan di RPP selanjutnya peneliti melakukan cross check variasi penilaian pengetahuan yang dapat dilakukan oleh 18 Guru PJOK SMP Negeri Malang. Berikut ini adalah hasil analisis berbagai pelaksanaan variasi penilaian pengetahuan yang telah dilakukan. 
Tabel 8. Analisis Data Pelaksanaan Variasi Penilaian Pengetahuan yang telah Dilakukan

\begin{tabular}{clccc}
\hline No & Bentuk & $\sum \mathbf{N}_{\text {RPP }}$ & $\sum$ fdDNS & \% \\
\hline 1 & Tes tulis & 124 & 49 & 39,52 \\
2 & Tes lisan & 124 & 1 & 0,81 \\
3 & Penugasan & 124 & 94 & 75,81 \\
\hline
\end{tabular}

\section{Keterangan:}

$\sum \mathrm{N}_{\mathrm{RPP}}=$ Jumlah keseluruhan RPP dari 18 guru; $\sum \mathrm{f}_{\mathrm{DNS}}=$ Jumlah Daftar Nilai yang Sesuai RPP; $(\%)=$ persentase

Berdasarkan hasil analisis data pada tabel 8 penilaian pengetahuan yang telah dilakukan sesuai materi di RPP cenderung dengan teknik penugasan, yaitu sebesar 75,81\% dengan kategori "baik". Sementara itu, tes tulis atau ulangan harian yang dapat dilakukan sesuai dengan materi di RPP sebesar 39,52\% dengan kategori "tidak baik". Penggunaan teknik penilaian dengan tes lisan yang telah dilakukan sesuai materi di RPP hanya 0,81\% dengan kategori "kurang baik". Dengan demikian, dapat disimpulkan bahwa pelaksanaan penilaian pengetahuan secara formatif belum berjalan sesuai rancangan penilaian di RPP. Selain itu, masih terdapat guru yang menilai pengetahuan di luar dari materi di RPP. Setelah analisis penilaian formatif maka langkah selanjutnya peneliti menganalisis penilaian sumatif pada aspek pengetahuan.

Pelaksanaan penilaian sumatif terdiri dari Penilaian Tengah Semester (PTS) dan Penilaian Akhir Semester (PAS). Dikarenakan keterbatasan waktu dan tenaga, maka peneliti hanya menganalisis kualitas soal PAS saja pada penilaian sumatif. sebab peneliti berasumsi bahwa soal PAS memiliki ruang lingkup materi lebih banyak dari soal PTS. Berikut ini adalah hasil analisis data dari 18 paket soal PAS PJOK pada sembilan SMPN di kota Malang dari kelas VII dan VIII pada semester I dengan jumlah keseluruhan butir soal 880 terhadap level kognitif Taksonomi Bloom revisi.

Tabel 9. Hasil Analisis Data Soal PAS PJOK SMPN Kota Malang terhadap Level Kognitif

\begin{tabular}{|c|c|c|c|c|c|c|c|c|c|c|c|c|}
\hline \multirow{2}{*}{$\underset{\text { Soal }}{\sum \mathbf{N}}$} & \multicolumn{2}{|c|}{ Mengingat (C1) } & \multicolumn{2}{|c|}{ Memahami (C2) } & \multicolumn{2}{|c|}{ Menerapkan (C3) } & \multicolumn{2}{|c|}{ Menganalisis (C4) } & \multicolumn{2}{|c|}{ Mengevaluasi (C5) } & \multicolumn{2}{|c|}{ Mengkreasi (C6) } \\
\hline & $\sum \mathbf{f}$ & $(\%)$ & $\sum \mathbf{f}$ & $(\%)$ & $\sum f$ & $(\%)$ & $\sum \mathbf{f}$ & $(\%)$ & $\sum \mathbf{f}$ & $(\%)$ & $\sum \mathbf{f}$ & $(\%)$ \\
\hline 880 & 106 & 12,05 & 361 & 41,02 & 405 & 46,02 & 8 & 0,91 & 0 & 0 & 0 & 0 \\
\hline
\end{tabular}

\section{Keterangan:}

$\sum \mathrm{N}=$ jumlah keseluruhan butir soal PAS; $\sum \mathrm{f}=$ jumlah soal dengan tingkat kognitif taksonomi bloom revisi; $(\%)=$ persentase

Berdasarkan tabel 9 di atas dapat disimpulkan bahwa dari 18 paket soal PAS dengan sampel sembilan SMP Negeri di kota Malang pada soal PAS PJOK kelas VII dan VIII Tahun Pelajaran 2018/2019 masih sebagian besar belum mencapai level kognitif yang tinggi atau HOTS. Hal tersebut terbukti karena hanya 0,91\% yang hanya mencapai level menganalisis (C4), sedangkan di level kognitif mengingat (C1) sebesar 12,05\%, memahami (C2) sebesar 41,02\%, dan menerapkan (C3) sebesar 46,02\%. Pada soal PAS PJOK tersebut belum mencapai level kognitif mengevaluasi (C5) dan mengkreasi (C6). Dengan demikian, dapat disimpulkan bahwa soal PAS yang disusun guru PJOK SMP Negeri kota Malang belum memiliki kualitas HOTS atan level kognitif yang tinggi secara dominan. Setelah menganalisis studi dokumen perangkat pembelajaran dan dokumen penilaian guru, maka peneliti juga menyajikan kesimpulan dari data wawancara dari guru PJOK.

Berikut ini adalah hasil kesimpulan wawancara dari 18 guru PJOK di Kota Malang. Adapun pelaksanaan penilaian pengetahuan PJOK secara umum yaitu (1) penilaian pengetahuan dinilai per KD dengan bentuk, antara lain (1) tes objektif berupa pilihan ganda atau tes subjektif berupa uraian; (2) pemberian tugas berupa membuat rangkuman materi, menganalisis video, membuat variasi gerakan, dan tugas lainnya; (3) tes lisan yaitu guru memberikan pertanyaan kepada siswa secara lisan dan mereka juga menjawabnya dengan lisan baik satu per satu maupun secara acak; (4) Penilaian Tengah Semester (PTS); (5) Penilaian Akhir Semester (PAS).

Adapun kendala yang selama ini terjadi ketika melakukan penilaian pengetahuan antara lain: (1) keterbatasan waktu, (2) minat siswa masih rendah dalam membaca materi, (3) siswa lebih senang praktik daripada teori, (4) daya ingat siswa rendah dalam mempelajari pengetahuan, dan (5) pemahaman siswa masih rendah jika tidak dijelaskan dengan rinci. Adapun tindak lanjut hasil penilaian pengetahuan dilakukan dengan remidi dan pengayaan. Remidi diberikan apabila siswa memperoleh nilai di bawah KKM yang dilakukan dengan cara antara lain (1) memberikan tugas, (2) memberikan soal yang bobotnya lebih rendah atau berbeda, (3) mengerjakan soal yang sama, (4) mengerjakan kembali soal yang dijawab salah dan boleh melihat sumber belajar, (6) memberikan review kembali, (7) memberikan tes secara lisan. Pengayaan diberikan bagi siswa yang nilainya di atas KKM yang dilakukan dengan cara (1) memberikan soal yang bobotnya lebih tinggi atau berbeda dan (2) membenarkan jawaban yang salah dari soal yang dibenarkan dengan menjabarkan secara rinci.

Adapun nilai rapor pada aspek pengetahuan merupakan rata-rata yang diperoleh dari (1) nilai ulangan harian dan tugas per KD, (2) penilaian tengah semester, (3) penilaian akhir semester (PAS). KD yang tidak dapat dilakukan untuk penilaian pengetahuan yaitu terdiri dari (1) renang yang diungkapkan sebanyak 17 guru, (2) beladiri yang diungkapkan sebanyak lima guru, dan (3) KD yang lingkupnya tentang kesehatan yaitu diungkapkan sebanyak 2 guru. Alasan guru tidak mengajarkan KD 
tersebut, yaitu (1) tidak tersedianya fasilitas untuk KD renang, (2) kesepakatan antar MGMP sekolah bahwa tidak diberikan materi pada KD beladiri dikarenakan terdapat ekstrakurikuler karate di sekolah, dan (3) pemilihan fokus untuk salah satu KD kesehatan yaitu antara KD 3.9 atau 3.10 baik kelas VII maupun kelas VIII.

Berdasarkan keseluruhan analisis data yang diperoleh, maka dapat disimpulkan bahwa pelaksanaan penilaian pengetahuan PJOK selama semester I sudah berjalan dengan baik. Namun, masih perlu diperbaiki dari beberapa aspek, seperti (1) instrumen penilaian pengetahuan di RPP belum standar dan fungsional, (2) soal sebagian besar hanya sampai level C1 - C3 belum menyajikan soal tingkat kognitif C4-C6, (3) guru belum aktif dalam mencatat jumlah benar-salah (skor mentah) siswa setelah mengerjakan soal padahal data tersebut dapat digunakan untuk menganalisis kualitas instrumen penilaian, (4) guru belum menggunakan berbagai variasi penilaian pengetahuan terutama tes lisan, dan (5) tes lisan digunakan hanya pada akhir pembelajaran saja, itu pun dilakukan secara acak dan sebagian besar tidak didokumentasikan untuk penilaian pengetahuan.

\section{Hasil Analisis Data Pelaksanaan Penilaian Keterampilan PJOK di SMP Negeri Malang}

Pelaksanaan penilaian keterampilan PJOK di Kota Malang diperoleh dari tes praktik, proyek, dan portofolio. Tes praktik yaitu menilai aspek psikomotor siswa dalam melakukan tugas gerak sesuai materi telah diajarkan oleh guru PJOK. Tes praktik dalam PJOK dapat diukur dari aspek kebenaran gerak yang disebut dengan penilaian proses dan prestasi hasil kemampuan siswa yang disebut dengan penilaian produk. Penilaian proyek yaitu memberikan tugas siswa dalam jangka waktu tertentu untuk membuat karya, biasanya terdiri dari perencanaan, pelaksanaan, dan pelaporan. Penilaian portofolio adalah kumpulan dari berbagai prestasi atau karya siswa selama mengikuti pembelajaran PJOK.

Berikut ini adalah hasil analisis data menggunakan studi dokumen tentang kualitas kelengkapan komponen penilaian keterampilan yang ditinjau dari adanya petunjuk pelaksanaan, rubrik, kriteria penyekoran, dan pengolahan skor akhir yang disusun dalam RPP dari 18 guru PJOK SMP Negeri Malang pada semester I tahun pelajaran 2018/2019.

Tabel 10. Analisis Data Kelengkapan Komponen Instrumen Penilaian Keterampilan di RPP

\begin{tabular}{lclllll}
\hline Indikator & No & Bentuk & fRPP & NSkor & fSkor & $(\boldsymbol{\%})$ \\
\hline (1) petunjuk melakukan & 1 & Tes praktik & 227 & 908 & 723 & 79,63 \\
(2) rubrik & 2 & Proyek & 23 & 92 & 57 & 61,96 \\
(3) kriteria penyekoran & 3 & Portofolio & 22 & 88 & 55 & 62,5 \\
\cline { 2 - 7 } (4) pengolahan skor akhir & & Jumlah & $\mathbf{2 8 2}$ & $\mathbf{1 1 2 8}$ & $\mathbf{8 5 5}$ & $\mathbf{7 5 , 8}$ \\
\cline { 2 - 7 } & & & & &
\end{tabular}

\section{Keterangan:}

$\mathrm{f}_{\mathrm{RPP}}=$ Jumlah yang ada di setiap RPP 18 guru; Nskor = skor maksimal; fskor $=$ skor hasil; $(\%)=$ persentase

Berdasarkan hasil analisis data tabel 10 tentang kelengkapan komponen instrumen penilaian keterampilan dalam RPP yang disusun oleh 18 guru PJOK, secara keseluruhan diperoleh skor 75,8\% sehingga dapat dikategorikan "baik". Hal tersebut belum mencapai sangat baik karena instrumen penilaian keterampilan pada teknik tes praktik sebagian besar belum disertai petunjuk melakukan dan kriteria penyekorannya. Penggunaan rentang skala pada tes praktik, meliputi 0-1, 1-2, 1-3, 1-4, atau 1-5 terkadang belum dijelaskan apa saja kriteria untuk indikator memperoleh skor 1, 2, 3, 4, atau 5 jika melakukan tes praktik. Selain itu, penyusunan rancangan penilaian keterampilan berupa proyek dan portofolio hanya sebanyak empat guru PJOK.

Setelah menganalisis kualitas kelengkapan komponen instrumen penilaian keterampilan di RPP selanjutnya peneliti melakukan cross check variasi bentuk pencatatan dokumen penilaian keterampilan yang dapat dilakukan oleh 18 Guru PJOK SMP Negeri Malang. Berikut ini adalah hasil analisis berbagai pelaksanaan variasi penilaian keterampilan yang telah dilakukan sesuai dengan materi dan indikator pada RPP yang dibuat guru.

Tabel 11. Data Pelaksanaan Bentuk Penilaian Keterampilan yang telah Dilakukan

\begin{tabular}{clcccccc}
\hline \multirow{2}{*}{ No } & \multirow{2}{*}{ Bentuk Penilaian } & \multicolumn{3}{c}{ Dokumen Skor Mentah } & \multicolumn{3}{c}{ Dokumen Nilai Akhir (1-100) } \\
\cline { 3 - 8 } & & $\mathbf{N}_{\text {RPP }}$ & $\mathbf{f}_{\text {DNS }}$ & \% & $\mathbf{N}_{\text {RPP }}$ & $\mathbf{f}_{\text {DNS }}$ & \% \\
\hline 1 & Tes praktik: proses & 207 & 44 & 21,26 & 207 & 100 & 48,31 \\
2 & Tes praktik: produk & 66 & 31 & 46,97 & 66 & 31 & 46,97 \\
3 & Proyek & 23 & 0 & 0 & 23 & 5 & 21,74 \\
4 & Portofolio & 22 & 0 & 0 & 22 & 0 & 0 \\
\hline
\end{tabular}

\section{Keterangan:}

$\mathrm{N}_{\mathrm{RPP}}=$ Jumlah Rancangan Penilaian pada Materi RPP tiap guru; $\mathrm{f}_{\mathrm{DNS}}=$ Daftar Nilai yang Sesuai Perencanaan Penilaian di RPP; $(\%)=$ persentase 
Berdasarkan hasil analisis data pada tabel 11, penilaian keterampilan yang dilakukan sesuai dengan perencanaan penilaian keterampilan dengan menggunakan tes praktik melalui pendekatan proses sebesar 48,31\% dengan kategori "kurang baik". Penilaian keterampilan dengan menggunakan tes praktik melalui pendekatan produk sebesar 48,31\% dengan kategori "kurang baik". Hal tersebut terjadi karena cara menilai guru dengan tes praktik tidak sesuai dengan materi di RPP. Beberapa kasus terjadi yaitu penilaian keterampilan pada RPP menggunakan tes praktik dengan pendekatan proses, tetapi kenyataannya menggunakan pendekatan produk, begitu juga sebaliknya. Selain itu, bentuk penilaian tes keterampilan di luar konteks indikator materi pada RPP. Bahkan juga ada yang terjadi penilaian keterampilan dilakukan di luar materi dari RPP. Selain itu guru juga jarang mendokumentasikan skor mentah dari hasil keterampilan siswa dengan tes praktik pendekatan proses, karena hanya $21,26 \%$ guru yang mendokumentasikan skor mentah dari rubrik penilaian sesuai materi indikator di RPP. Sebagian besar guru menyatakan bahwa mereka hanya menjalankan tuntutan tagihan nilai yaitu dengan skala 1-100. Jadi, mereka menganggap bahwa dokumen skor mentah dari rubrik penilaian tidak penting.

Penilaian keterampilan berbasis proyek masih jauh dari standar, karena hanya empat guru yang menyusun instrumen penilaian proyek. Dari empat guru tersebut hanya berjalan sebesar 21,74\% dengan kategori "tidak baik". Terdapat beberapa guru yang melakukan penilaian berbasis proyek, namun tidak dilandasi instrumen penilaian yang jelas. Semnetara itu, pada penilaian portofolio, empat guru memang merancang instrumen tersebut, tetapi mereka mengartikan bahwa penilaian portofolio didapat dari rata-rata kumpulan tugas atau prestasi siswa.

Berikut ini adalah hasil temuan wawancara dari 18 guru PJOK SMPN di kota Malang, yaitu penilaian keterampilan diperoleh dari (1) tes praktik berupa kebenaran gerak dan hasil atau produk gerakan; (2) proyek berupa membuat sebuah kreasi dapat berbentuk: rangkaian gerakan, modifikasi alat olahraga, dokumen variasi latihan gerakan; (3) portofolio berupa kumpulan tugas dari siswa dapat berbentuk kliping, karya tulisan, dan laporan pengamatan gerakan.

Adapun kendala yang terjadi selama penilaian keterampilan, meliputi (1) keterbatasan fasilitas, (2) keberagaman kemampuan psikomotor siswa, (3) kondisi lingkungan atau cuaca, (4) adanya kegiatan sekolah yang mendadak, (5) keberanian siswa melakukan gerakan tertentu, (6) tugas mendadak yang diberikan kepada guru PJOK, dan (7) keterbatasan waktu. Adapun tindak lanjut dari hasil penilaian keterampilan pada tes praktik dilakukan dengan remidi dan pengayaan. Remidi diberikan kepada siswa yang belum memenuhi indikator ketentuan gerak. Remidi dilakukan dengan cara (1) memberikan kesempatan berlatih baik secara bimbingan guru, teman sejawat, atau mandiri, kemudian diberi kesempatan dites ulang; (2) menilai kemampuan siswa sebisanya yang terpenting sikap siswa baik selama mengikuti pelajaran maka diberikan nilai sesuai KKM. Pengayaan dilakukan dengan memberikan tugas gerak yang bobotnya lebih tinggi dari sebelumnya.

Nilai keterampilan di rapor diperoleh dari rata-rata dari nilai keterampilan per KD. Nilai per KD terdiri dari nilai praktik, proyek, dan portofolio kemudian diambil perwakilan nilai tertinggi jika KD terdiri dari beberapa materi. Kompetensi Dasar yang tidak dapat dilakukan penilaian keterampilan, yaitu (1) renang dan (2) beladiri yang diungkapkan sebanyak lima guru dengan alasan (1) tidak tersedianya fasilitas untuk KD renang, (2) kesepakatan antar MGMP sekolah bahwa pada KD beladiri siswa dapat mengikuti ekstrakurikuler karate, dan (3) keterbatasan waktu.

Dengan demikian, dapat disimpulkan bahwa pelaksanaan penilaian keterampilan PJOK pada SMP Negeri Kota Malang masih jauh dari standar materi di RPP. Hal tersebut dikarenakan (1) guru tidak menilai keterampilan sesuai dengan rubrik penilaian di RPP, (2) guru jarang mencatat atau mendokumenkan skor mentah yang diperoleh siswa, (3) hanya penilaian tes praktik berbasis produk saja yang guru dokumentasikan skor mentahnya, (4) sebagian besar guru menilai langsung dengan nilai jadi (skala 1-100), karena nilai itu yang diminta oleh pihak sekolah untuk pengisian rapor, dan (5) guru jarang menggunakan penilaian berbasis proyek dan portofolio dengan cara yang standar.

\section{PEMBAHASAN}

Penilaian dalam pembelajaran merupakan upaya guru untuk memperoleh informasi dari sikap, pengetahuan, dan keterampilan siswa. Dalam kurikulum 2013 revisi 2016, penilaian pada mata pelajaran PJOK yang menjadi tagihan guru hanya penilaian pengetahuan dan keterampilan. Pada penilaian sikap secara dominan diserahkan kepada guru BK, PPKn, dan PABP. Namun dalam PJOK guru juga dianjurkan menilai sikap melalui pembelajaran tidak langsung. Dari hasil analisis data pelaksanaan penilaian pada aspek pengetahuan PJOK pada SMPN Malang dengan sampel sembilan sekolah atau 18 guru antara KD yang telah dipilih untuk dinilai dan direncanakan rata-rata dapat berjalan sekitar 77,42\% dengan kategori "baik". Hal tersebut disebabkan berbagai faktor, antara lain: (1) keterbatasan fasilitas olahraga, (2) keterbatasan waktu dalam mengajar karena waktu pembelajaran terpotong akibat kegiatan sekolah yang mendadak, (3) keterbatasan kemampuan guru dalam mencapai target dalam tagihan penilaian sesuai dengan RPP. Hal tersebut selaras dengan hasil penelitian tentang kesulitan guru dalam mengimplementasikan penilaian autentik pada kurikulum 2013, yaitu (1) kurangnya pemahaman guru, (2) rendahnya kreativitas guru, (3) karakteristik siswa yang tidak mendukung, (4) kurangnya pelatihan, dan (4) keterbatasan waktu (Enggarwati, 2015). Hasil penelitian lain tentang pelaksanaan penilaian kelas pada mata pelajaran matematika SMP Negeri di Kabupaten Lombok Tengah karena sudah dilaksanakan dengan baik dari segi teknik, prosedur, dan pelaporan serta pemanfaatan hasil (Yunus \& Retnowati, 2014). Berbeda dengan kualitas penilaian pembelajaran matematika SMP Negeri kelas VII di kabupaten Sleman dalam implementasi kurikulum 2013 termasuk pada kompetensi pengetahuan termasuk kategori kurang baik (Abrory \& Kartowagiran, 2014). 
Dengan demikian, diperlukan beberapa format penilaian yang terstruktur, standar, dan terdokumentasi. Penggunaan format penilaian yang baik akan membantu para guru dalam memberikan penilaian partisipasi siswa dan tugas terstruktur (Noviana \& Kartowagiran, 2015). Selain itu, guru PJOK bertanggung jawab untuk membuat keputusan dari penilaian hasil belajar siswa sehingga guru harus menentukan pilihan bentuk penilaian yang mereka gunakan untuk mendapatkan informasi yang berkualitas dalam merekam kemajuan siswa selama proses pembelajaran PJOK (Kim, Lee, Ward, \& Li, 2015). Dengan demikian, melaksanakan penilaian pengetahuan dan keterampilan menjadi kewajiban guru PJOK. Berikut ini akan disajikan pembahasan secara mendalam mengenai penilaian pengetahuan dan keterampilan dalam PJOK di SMP Negeri Malang.

\section{Pelaksanaan Penilaian Pengetahuan PJOK di SMP Negeri Malang}

Pelaksanaan penilaian pengetahuan PJOK di SMPN Malang, meliputi penilaian formatif dan sumatif. Penilaian formatif telah disusun instrumennya pada masing-masing RPP yang dibuat guru. Hal tersebut selaras dengan pernyataan dari (Ani, 2017) yaitu dalam menyusun rencana pembelajaran, guru perlu memperhatikan instrumen penilaian yang digunakan harus memantau proses, kemajuan dan perbaikan hasil belajar siswa secara berkesinambungan. Penilaian sumatif yaitu terdiri dari PTS dan PAS. Penyusunan instrumen penilaian pengetahuan yang kontekstual, terpadu, berkesinambungan, berbasis kinerja dan memotivasi siswa untuk mengelolanya (Anisa, 2015). Oleh karena itu, instrumen penilaian pengetahuan harus jelas dan fungsional. Adapun kelengkapan instrumen penilaian pengetahuan di RPP pada pelajaran PJOK di Sembilan SMPN Malang rata-rata dapat dikategorikan "baik", karena sebagian besar belum dilengkapi petunjuk dan kunci jawaban atau rubrik penilaian dengan jelas. Hasil tersebut senada dengan penelitian dari (Winarno, Yudasmara, Taufik, \& Fadhli, 2019) bahwa instrumen penilaian yang dibuat guru PJOK dalam RPPnya cenderung berbentuk esai dan tidak dilengkapi kunci jawaban yang jelas, serta soal belum berkualifikasi HOTS.

Persepsi penilaian yang dilakukan oleh pemerintah dan pendidik masih berbeda, tanpa melihat proses di lapangan, UN yang terlalu dini, tanpa ada feedback, Penilaian sesuai standar kompetensi lulusan masih belum terlaksana sepenuhnya, Usaha: Hasil penilaian oleh pendidik hanya mengejar target saja yang telah ditetapkan oleh penilaian dari pemerintah (Raharjo, 2012). Penilaian dalam pembelajaran harus autentik dan benar-benar dapat mengukur kemampuan siswa yang sesungguhnya. Dimensi penilaian autentik yang telah diidentifikasi oleh (Frey, Schmitt, \& Allen, 2012) memiliki tiga dimensi besar yang masingmasing memiliki tiga indikator, yaitu (1) dimensi konteks penilaian yang terdiri dari (a) kegiatan atau konteks yang realistis, (b) penugasan berbasis kinerja, (c) penugasan melibatkan kognitif yang kompleks; (2) dimensi peran siswa terdiri dari: (a) memfasilitasi siswa untuk menyatakan jawaban atau menghasilkan produk (b) penilaian bersifat formatif, (c) memfasilitasi siswa untuk berkolaborasi satu sama lain atau dengan guru; (3) dimensi penskoran, meliputi (a) memiliki kriteria penilaian diketahui; (b) memiliki beberapa indikator; (c) mengukur penguasaan.

Hasil penelitian dari pelaksanaan penilaian pengetahuan secara formatif, guru PJOK di sembilan SMPN Malang cenderung menggunakan penugasan, misalnya merangkum materi, membuat kliping, membuat karya tulis, dan membuat laporan dalam mengamati sebuah peristiwa olahraga. Hal tersebut bertolak belakang dengan instrumen penilaian pengetahuan di RPP, sebab di RPP juga terdapat penilaian pengetahuan namun tidak digunakan. Pemberian nilai dalam tugas cenderung subjektif karena tidak memiliki acuan yang terukur pada rubrik penilaian pengetahuan pada RPP. Menurut (Rind \& Mari, 2019) model penilaian, praktik mengajar, dan pendekatan pembelajaran kepada siswa sangat berkorelasi. Oleh karena itu, penggunaan model penilaian sebaiknya dapat mengukur kompetensi siswa dengan tepat.

Dengan demikian, dalam memberikan penugasan hendaknya menggunakan rubrik penilaian yang jelas dan praktis, yaitu (1) menyajikan konten yang dinilai, (2) masing-masing konten memiliki indikator, dan (3) kemudian setiap indikator diukur dengan menggunakan skor. Hasil penilaian formatif hendaknya memiliki kriteria yang jelas, dapat dipertanggungjawabkan serta dapat mengidentifikasi kemampuan siswa secara tepat dapat menunjukkan kelemahan dan keunggulan siswa.

Hasil analisis instrumen pengetahuan PJOK pada jenjang SMPN Malang yang disusun pada penilaian formatif dan sumatif masih sebagian besar berkisar antara memahami (C2) dan menerapkan (C3). Untuk dapat menyusun atau mengonstruksikan soal-soal HOTS dengan tepat, sesuai dengan karakteristik mata pelajaran tertentu, diperlukan pemahaman terlebih dahulu tentang konsep dan karakteristik HOTS (Pratiwi, Hidayah, \& Martiana, 2017). Siswa seharusnya memecahkan pertanyaan dengan dimensi proses kognitif yang tinggi karena untuk meningkatkan keterampilan berpikir tingkat tinggi mereka (Karadeniz, Baran, Gökçek, \& Güç, 2015). Metode penilaian yang digunakan di sekolah jika hanya tingkatan mengingat (C1) sampai menerapkan (C3) tidak akan membantu siswa dalam meningkatkan keterampilan berpikir tingkat tinggi mereka (Abosalem, 2016).

Hasil review dari (Adams, 2015) menjelaskan bahwa dewasa ini setiap guru ingin mengembangkan keterampilan berpikir siswa pada tingkat taksonomi bloom yang tinggi seperti berpikir kritis dan evaluatif, tetapi kenyataannya telah menunjukkan bahwa tujuan pembelajaran dalam program pada kurikulum berfokus pada keterampilan kognitif level rendah (pengetahuan dan pemahaman). Kelemahan tersebut perlu diperbaiki jika guru ingin mencapai peningkatan keterampilan berpikir kritis bagi siswa. Dengan demikian sebaiknya pertanyaan disajikan dengan urutan dari yang sederhana sampai dengan yang kompleks yaitu mengingat sampai mengkreasi sehingga dapat mendorong pengembangan tingkat berpikir siswa dan tidak hanya sekedar mengingat, memahami, dan mengaplikasikan saja. 
Penilaian pengetahuan berperan sangat penting dan dapat memengaruhi performa peserta didik karena dengan tes kognitif dapat mengukur dan menguji peran keterlibatan kognitif dalam suatu proses praktik gerak (Smiley \& Anderson, 2011). Menurut (Salimin, Jani, Shahril, \& Elumalai, 2015) penggunaan penilaian komprehensif pada aspek pengetahuan yang berdasarkan tingkat berpikir taksonomi Bloom yang telah diuji validitas dan reliabilitasnya tepat digunakan oleh guru sebagai instrumen standar untuk menilai prestasi siswa untuk mata pelajaran Pendidikan Jasmani pada sekolah-sekolah di Malaysia. Hal tersebut dikarenakan lebih realistis, holistik dan mampu menilai siswa sepenuhnya sesuai dengan filosofi pendidikan nasional dan secara tidak langsung menunjukkan tingkat kemampuan pengetahuan siswa dalam mata pelajaran PJOK.

Penilaian pengetahuan harus sistematis dan tidak hanya mengandalkan penilaian dari PTS maupun PAS saja. Seorang guru harus melakukan penilaian yang benar-benar mengukur hasil siswa pembelajaran di setiap sesi dengan valid disertai pedoman yang jelas (Metzler, 2011). Dengan demikian, instrumen penilaian harus benar-benar valid, reliabel, dan objektif serta praktis digunakan. Integrasi yang bijaksana dari pendekatan penilaian harus mengarah pada keputusan formatif yang valid, jika berbagai bukti dari hasil belajar siswa digunakan untuk terus mengoptimalkan pembelajaran (Van der Kleij, Vermeulen, Schildkamp, \& Eggen, 2015). Penilaian pengetahuan dalam PJOK selain mengetahui kemampuan siswa juga mengetahui kualitas kinerja guru dalam melakukan pembelajaran (Collier, 2011).

Pelaksanaan penilaian pengetahuan dalam PJOK pada SMPN Malang sebaiknya mengacu pada standar penilaian yang berlaku. Selain itu, instrumen penilaian pengetahuan pada RPP harus disusun dengan kriteria yang jelas, tepat, dan praktis. Selanjutnya perlu ditambahkan kualifikasi soal yang proporsional antara level kognitif mengingat, memahami, menerapkan, menganalisis, mengevaluasi, dan mengkreasi. Sebab dengan penyajian soal HOTS, diharapkan siswa dapat meningkatkan keterampilan berpikir kritis.

\section{Pelaksanaan Penilaian Keterampilan PJOK di SMP Negeri Malang}

Pelaksanaan penilaian keterampilan PJOK di sembilan SMPN Malang terdiri dari tes praktik, proyek, dan portofolio. Instrumen penilaian keterampilan dengan teknik tes praktik selalu disusun semua guru PJOK di RPPnya masing-masing. Dalam instrumen tes praktik dalam RPP PJOK rata-rata memiliki kelengkapan komponen sebesar 79,63\% tergolong "baik". Hal tersebut belum mencapai kategori "sangat baik" karena sebagian guru belum memberikan kriteria penyekoran dengan jelas. Instrumen penilaian PJOK yang dirancang hendaknya dengan sistematis untuk mengukur variabel yang terkait dengan materi dan bersifat objektif. Kemudian didasari dengan kerangka teoritis yang diuraikan dengan panduan prosedur dan metode pencatatan yang jelas sehingga data hasil penilaian dapat disimpulkan (Curtner-Smith \& Todorovich, 2002). Selain itu, kriteria penyekorannya juga menggunakan skala yang bervariasi. Penggunaan norma yang berbeda dapat menghasilkan keputusan yang berbeda tentang diagnosis dan akomodasi pembelajaran (Harrison, Butt, \& Armstrong, 2019).

Hasil review dari (López-Pastor, Kirk, Lorente-Catalán, MacPhail, \& Macdonald, 2013) dalam PJOK penilaian tradisional dari alat-alat non-pendidikan, seperti tes kebugaran jasmani dan kriteria subjektif lebih populer digunakan daripada penilaian alternatif. Penilaian alternatif atau dengan rubrik penilaian berorientasi pada proses dapat membantu guru PJOK untuk mengukur kelebihan dan kekurangan siswa sehingga membantu siswa untuk mempelajari konsep dan keterampilan yang lebih produktif dan gaya hidup sehat di masa depan (Schincariol \& Radford, 2013). Tes untuk menguji keterampilan motorik harus mempertimbangkan sejumlah faktor termasuk biaya, waktu dan ruang yang tersedia, jumlah tester dalam kelompok, dan pengalaman penguji (Ali, 2011). Guru PJOK disarankan mengelola tes keterampilan motorik dengan berkala, sebab mereka dapat bertindak sebagai agen dalam mengidentifikasi perkembangan motorik siswa serta dapat membuat rujukan yang tepat berdasarkan hasil penilaian motorik tersebut (Logan, Robinson, Rudisill, Wadsworth, \& Morera, 2014). Penilaian keterampilan PJOK yang berkualitas tinggi harus disertai dengan kriteria penilaian yang jelas, bermakna, dan kredibel (Chen, Lui, Andrade, Valle, \& Mir, 2017). Guru PJOK perlu menggambarkan tujuan dan kriteria penilaian dengan jelas serta menggunakan penilaian yang sesuai dengan perkembangan dan usia untuk memastikan sifat edukatif penilaian dalam pembelajaran selain evaluasi (Starck, 2018).

Hasil penelitian menunjukkan bahwa kompetensi motorik dan kebugaran jasmani berhubungan dengan kesehatan pada remaja di masa mendatang (Cattuzzo et al., 2016). Hasil temuan penelitian dari (Baharom, Khoiry, Hamid, Mutalib, \& Hamzah, 2015), bahwa mayoritas siswa mendapatkan nilai terbaik ketika ujian, namun tidak diimbangi dengan domain psikomotor sehingga perlu dilakukan perbaikan untuk meningkatkan kesadaran siswa tentang pentingnya kemampuan psikomotor. Demikian pelaksanaan penilaian keterampilan dalam PJOK seharusnya dilakukan dengan benar karena penilaian keterampilan berfungsi untuk mengetahui kemampuan motorik siswa. Jika data penilaian tepat, maka guru PJOK dapat mengkreasi berbagai model pembelajaran yang dapat mendorong siswa untuk terlibat aktif untuk meningkatkan keterampilan motorik.

Penilaian keterampilan yang akurat dan komprehensif menjadi semakin penting karena akan memberikan pemahaman tentang hubungan antara tingkat kemampuan motorik dan kesehatan (Logan, Barnett, Goodway, \& Stodden, 2017). Penggunaan rubrik penilaian sangat penting dalam pembelajaran untuk memoderasi hasil belajar siswa serta dapat dianggap sebagai aspek paling signifikan untuk penilaian yang akurat dan konsisten (Grainger \& Weir, 2016). Penilaian dapat dipandang sebagai bagian berkelanjutan dari pengajaran yang terjadi selama proses pembelajaran yaitu, tujuan utama penilaian adalah untuk memberikan umpan balik kepada siswa dan guru (Nordrum, Evans, \& Gustafsson, 2013). Guru PJOK harus memutuskan apakah nilai harus didasarkan pada proses, produk, atau kombinasi dari keduanya. Pada pelaksanaan tes praktik PJOK di sembilan SMPN Malang baik proses maupun produk masih jauh dari standar karena laporan penilaian belum tentu sesuai dengan rubrik penilaian di 
RPP. Temuan penelitian menyatakan bahwa aktivitas fisik dalam program di sekolah dapat berdampak pada keterampilan kognitif, sikap dan perilaku akademik, yang semuanya merupakan komponen penting dari peningkatan peforma akademik (Ardoy et al., 2014). Dengan demikian bentuk penilaian keterampilan terutama pada tes praktik dalam materi PJOK harus dilakukan dengan sungguh-sungguh, agar memperoleh informasi kemampuan fisik dan motorik peserta didik dengan tepat.

Berdasarkan Kurikulum 2013 revisi 2016 pada mekanisme penilaian keterampilan dilakukan melalui praktik, produk, proyek, portofolio, dengan kompetensi yang dinilai. Hal tersebut membuktikan bahwa penilaian keterampilan tidak hanya menggunakan praktik saja dalam kurikulum 2013 revisi 2016, namun juga diperlukan penilaian proyek maupun portofolio. Sehingga penilaian keterampilan memiliki berbagai variasi teknik. Penilaian proyek adalah penilaian yang menyeluruh tentang kemampuan mahasiswa melalui tugas yang mengandung investigasi dan harus terselesaikan dalam waktu tertentu. Penilaian proyek yang autentik dengan pendekatan saintifik yang dapat meningkatkan keterampilan berpikir ilmiah (Wijayanti, 2014). Hasil temuan dalam penilaian keterampilan PJOK dari 18 guru hanya empat guru yang menyusun instrumen penilaian proyek di RPPnya. Namun, karena tagihan nilai dalam kurikulum 2013 revisi 2016 harus melampirkan penilaian proyek, maka beberapa guru melakukan penilaian proyek tanpa dilandasi instrumen penilaian di RPPnya. Hal tersebut mengakibatkan bahwa penilaian proyek belum standar karena tidak menggunakan alat ukur yang jelas dan belum objektif.

Penilaian portofolio merupakan sistem penilaian pembelajaran dalam konteks nyata dan responsif dengan pengaturan naturalistik, yaitu mendokumentasikan pembelajaran siswa secara autentik yang dapat meningkatkan motivasi siswa untuk belajar dalam pendidikan jasmani karena mencerminkan nilai-nilai siswa dalam pengetahuan, keterampilan, dan perilaku sosial (Kirk, 2013). Penilaian portofolio dalam PJOK untuk mendokumentasikan kemampuan siswa karena untuk memperoleh data yang bersifat nyata dan dinamis sehingga dapat memberikan tantangan siswa yang lebih tinggi (Lester, 2015). Hasil temuan penelitian pelaksanaan penilaian PJOK SMPN Malang guru mengartikan penilaian portofolio menjadi beberapa persepsi, yaitu (1) penilaian portofolio adalah kumpulan tugas siswa, (2) penilaian portofolio adalah hasil prestasi kualitas dari tes motorik siswa, dan (3) penilaian portofolio adalah karya tulis yang dibuat oleh siswa di setiap materi. Dengan demikian, perlu adanya penyamaan persepsi antar guru PJOK mengenai penilaian portofolio.

Pelaksanaan penilaian keterampilan dalam PJOK pada SMPN Malang sebaiknya mengacu pada standar penilaian yang baik minimal memiliki kriteria valid, reliabel, dan objektif. Selain itu, instrumen penilaian keterampilan pada RPP harus disusun dengan kriteria yang jelas dan tepat. Selanjutnya, perlu ditambahkan rubrik penilaian proyek atau portofolio di beberapa RPP yang memungkinkan teknik penilaian tersebut sesuai dengan materi yang diajarkan. Sebab tuntutan penilaian keterampilan pada kurikulum 2013 revisi 2016 harus melibatkan penilaian proyek dan portofolio. Selain itu, hendaknya guru juga mendokumentasikan skor mentah atau dokumen rubrik penilaian dari hasil tes praktik keterampilan siswa. Sebab skor mentah tersebut dapat berfungsi untuk mengetahui kelebihan dan kelemahan siswa secara rinci.

\section{SIMPULAN}

Simpulan pelaksanaan penilaian pengetahuan dan keterampilan PJOK selama semester I di SMP Negeri di kota Malang dengan sampel sembilan sekolah rata-rata dapat dikatakan "baik". Belum mencapai pada kategori sangat baik karena masih ditemukan kesenjangan antara perencanaan materi di RPP dengan catatan dokumen penilaian. Hal tersebut dikarenakan catatan dokumen penilaian belum selaras dengan materi yang disusun dalam RPP. Selain itu, juga ditemukan penilaian yang dilakukan di luar konteks materi yang disusun dari RPP.

Pelaksanaan penilaian pengetahuan diperoleh dari penilaian harian, PTS, dan PAS. Akan tetapi, penilaian harian sebagian besar menggunakan penugasan dan jarang menggunakan tes lisan. Sehingga rubrik penilaian pengetahuan di RPP belum fungsional. Instrumen penilaian pengetahuan di RPP ditinjau dari aspek (1) petunjuk mengerjakan, (2) kunci jawaban atau rubrik, dan (3) pengolahan skor hasil dapat dikatakan "cukup baik". Sebagian besar jenis soal yang disajikan pada RPP adalah esai. Instrumen penilaian pengetahuan sebagian besar belum memiliki petunjuk cara mengerjakan dan kunci jawaban yang jelas. Kualifikasi soal pada penilaian pengetahuan belum mencapai pada level kognitif yang tinggi yaitu belum mencapai pada level menganalisis (C4) sampai mengkreasi (C6), namun hanya mencapai pada level mengingat (C1) sampai menerapkan (C3). Guru PJOK berasumsi karena pada tingkat jenjang SMP belum saatnya diberi soal dengan level kognitif C4 sampai C6. Pelaksanaan penilaian keterampilan diperoleh dari tes praktik baik dari pendekatan proses yaitu kebenaran melakukan gerakan dan produk atau hasil yaitu hasil yang dicapai dari tes praktik tersebut. Hanya sebagian kecil guru yang dapat melakukan penilaian keterampilan berbasis proyek dan portofolio dengan rancangan penilaian yang sesuai di RPPnya. Rubrik penilaian keterampilan yang disusun guru belum fungsional untuk mencatat hasil belajar gerak siswa. Instrumen penilaian keterampilan di RPP ditinjau dari aspek (1) petunjuk melakukan, (2) penyajian rubrik, (3) kriteria penyekoran, dan (4) pengolahan skor hasil akhir dapat dikatakan "baik". Akan tetapi, instrumen penilaian keterampilan belum memiliki petunjuk melakukan dan kriteria penyekoran dengan jelas.

Saran atau rekomendasi untuk pelaksanaan penilaian pengetahuan pada PJOK, antara lain (1) guru sebaiknya memperhitungkan jumlah materi yang dapat berjalan dalam menyusun rancangan penilaian pengetahuan dalam RPP agar perencanaan target penilaian pengetahuan benar-benar dapat dilakukan; (2) guru sebaiknya menyusun instrumen penilaian pengetahuan dengan komponen yang lengkap yang terdiri dari petunjuk, kunci jawaban beserta penyekorannya jika berbentuk esai, dan pengolahan untuk skor akhir; (3) guru sebaiknya juga menyajikan soal pengetahuan baik di RPP maupun dalam PTS dan PAS dengan level kognitif yang tinggi yaitu menganalisis (C4), mengevaluasi (C5), dan mengkreasi (C6); (4) guru 
seharusnya melakukan berbagai teknik penilaian dalam menilai aspek pengetahuan yaitu tes tulis, tes lisan, dan penugasan yang dijabarkan secara jelas kriteria penilaiannya di dalam RPP; (5) guru sebaiknya juga aktif mencatat jumlah jawaban benar dan salah (skor mentah) siswa setelah proses penilaian pengetahuan baik formatif maupun sumatif, karena dapat berfungsi untuk menganalisis butir soal sehingga validitas, reliabilitas, dan objektivitas soal dapat dianalisis; (6) guru sebaiknya aktif dalam mengikuti pelatihan, workshop, atau seminar tentang pembuatan soal yang berkualitas.

Saran atau rekomendasi untuk pelaksanaan penilaian keterampilan pada PJOK, antara lain (1) dalam menyusun rancangan penilaian keterampilan di RPP guru sebaiknya memperhitungkan jumlah waktu belajar, sarana-prasarana sekolah, jumlah rombongan belajar tiap kelas, karakteristik siswa agar perencanaan penilaian keterampilan benar-benar dapat dilakukan; (2) guru sebaiknya menyusun instrumen penilaian keterampilan dengan komponen yang lengkap dan jelas yang terdiri dari: petunjuk pelaksanaan, rubrik, kriteria penyekorannya, dan pengolahan untuk skor akhir; (3) apabila guru menggunakan penilaian keterampilan dengan teknik tes praktik dengan pendekatan produk atau hasil, seharusnya guru mencantumkan kriterianya tertinggi dan terendah dengan jelas; (4) berdasarkan anjuran kurikulum 2013 revisi 2016 guru seharusnya melakukan berbagai teknik penilaian dalam menilai aspek keterampilan siswa, yaitu tes praktik, proyek, dan portofolio yang dijabarkan secara jelas kriterianya di RPP sehingga nilai yang didapat siswa dapat dipertanggungjawabkan; (5) guru sebaiknya aktif mencatat hasil rubrik penilaian proses maupun produk (skor mentah) siswa setelah proses penilaian keterampilan dilakukan, jadi tidak langsung dengan nilai skala 1-100 karena dokumen tersebut dapat berfungsi untuk menganalisis dan menentukan validitas, reliabilitas, dan objektivitas instrumen penilaiannya; (6) guru sebaiknya turut aktif dalam mengikuti seminar, pelatihan, atau mengadakan workshop tentang penyusunan penilaian keterampilan yang berkualitas.

\section{DAFTAR RUJUKAN}

Abosalem, Y. (2016). Assessment Techniques and Students' Higher-Order Thinking Skills. International Journal of Secondary Education, 4(1), 1-11. https://doi.org/10.11648/j.ijsedu.20160401.11

Abrory, M., \& Kartowagiran, B. (2014). Evaluasi Implementasi Kurikulum 2013 pada Pembelajaran Matematika SMP Negeri Kelas VII di Kabupaten Sleman. Jurnal Evaluasi Pendidikan, 2(1), 50-59.

Adams, N. E. (2015). Bloom's Taxonomy of Cognitive Learning Objectives. Journal of the Medical Library Association: JMLA, 103(3), 152-153. https://doi.org/10.3163/1536-5050.103.3.010

Aji, B. S., \& Winarno, M. E. (2016). Pengembangan Instrumen Penilaian Pengetahuan Mata Pelajaran Pendidikan Jasmani Olahraga dan Kesehatan (PJOK) Kelas VIII Semester Gasal. Jurnal Pendidikan, 1(7), 1449-1463.

Ali, A. (2011). Measuring Soccer Skill Performance: A Review. Scandinavian Journal of Medicine \& Science in Sports, 21(2), 170-183. https://doi.org/10.1111/j.1600-0838.2010.01256.x

Ani, Y. (2017). Penilaian Autentik dalam Kurikulum 2013. In Seminar Nasional Implementasi Kurikulum 2013 (pp. 742-749). Tangerang: Universitas Pelita Harapan.

Anisa, A. A. (2015). Evaluasi Penerapan Penilaian Otentik dalam Kaitannya dengan Kesiapan SDM menghadapi MEA. In Prosiding Seminar Nasional (pp. 408-418).

Ardoy, D. N., Fernández-Rodríguez, J. M., Jiménez-Pavón, D., Castillo, R., Ruiz, J. R., \& Ortega, F. B. (2014). A Physical Education Trial Improves Adolescents' Cognitive Performance and Academic Achievement: The EDUFIT study. Scandinavian Journal of Medicine and Science in Sports, 24(1), 1-10. https://doi.org/10.1111/sms.12093

Ardyanto, E. R., Winarno, M. E., \& Adi, S. (2016). Pengembangan Instrumen Pengetahuan Mata Pelajaran Pendidikan Jasmani Olahraga Kesehatan (PJOK) untuk Siswa Kelas XII Sekolah Menengah Atas. Jurnal Pendidikan: Teori, Penelitian, dan Pengembangan, 1(10), 1897-1903.

Arikunto, S., \& Jabar, C. S. A. (2009). Evaluasi Program Pendidikan: Pedoman Teoretis Praktis bagi Mahasiswa dan Praktisi Pendidikan. Jakarta: Bumi Aksara.

Baharom, S., Khoiry, M. A., Hamid, R., Mutalib, A. A., \& Hamzah, N. (2015). Assessment of Psychomotor Domain in a Problem-Based Concrete Laboratory. Journal of Engineering Science and Technology, 10(1), 1-10.

Borghouts, L. B., Slingerland, M., \& Haerens, L. (2017). Assessment Quality and Practices in Secondary PE in the Netherlands. Physical Education and Sport Pedagogy, 22(5), 473-489. https://doi.org/10.1080/17408989.2016.1241226

Cattuzzo, M. T., dos Santos Henrique, R., Ré, A. H. N., de Oliveira, I. S., Melo, B. M., de Sousa Moura, M., ... Stodden, D. (2016). Motor Competence and Health Related Physical Fitness in Youth: A Systematic Review. Journal of Science and Medicine in Sport, 19(2), 123-129. https://doi.org/10.1016/j.jsams.2014.12.004

Chen, F., Lui, A. M., Andrade, H., Valle, C., \& Mir, H. (2017). Criteria-Referenced Formative Assessment in The Arts. Educational Assessment, Evaluation and Accountability, 29(3), 297-314. https://doi.org/10.1007/s11092-017-9259-z

Chng, L. S., \& Lund, J. (2018). Assessment for Learning in Physical Education: The What, Why, and How. Journal of Physical Education, Recreation \& Dance, 89(8), 29-34. https://doi.org/10.1080/07303084.2018.1503119

Collier, D. (2011). Increasing the Value of Physical Education. Journal of Physical Education, Recreation \& Dance, 82(7), 3841. https://doi.org/10.1080/07303084.2011.10598656

Curtner-Smith, M. D., \& Todorovich, J. R. (2002). The Physical Education Climate Assessment Instrument. Perceptual and Motor Skills, 95(2), 652-660. https://doi.org/10.2466/pms.2002.95.2.652 
Darmawan, I. (2018). Evaluasi Pembelajaran Pendidikan Jasmani, Olahraga, dan Kesehatan menggunakan Model Countenance di SMP/MTs Kecamatan Trenggalek. Tesis tidak diterbitkan. Universitas Negeri Malang, Malang.

Dhuhary, A. A. (2018). Evaluasi Pembelajaran Pendidikan Jasmani, Olahraga, dan Kesehatan Menggunakan Model Countenance di Sekolah Menengah Pertama dan Madrasah Tsanawiyah pada Yayasan An-Nur Kecamatan Bululawang Kabupaten Malang. Tesis tidak diterbitkan. Universitas Negeri Malang, Malang.

Dwiyogo, W. D. (2010). Dimensi Teknologi Pembelajaran Pendidikan Jasmani dan Olahraga. Malang: Wineka Media.

Dwiyogo, W. D. (2016). Pembelajaran Visioner. (Rosikah, Ed.). Jakarta: Bumi Aksara.

Enggarwati, N. S. (2015). Kesulitan Guru SD Negeri Glagah dalam Mengimplementasikan Penilaian Autentik pada Kurikulum 2013. Jurnal Pendidikan Guru Sekolah Dasar, 5(12), 1-7.

Farida, I. (2017). Evaluasi Pembelajaran Berdasarkan Kurikulum Nasional. Bandung: PT Remaja Rosdakarya.

Fathoni, A. F. (2017). Pengembangan Rubrik Penilaian Keterampilan Mata Pelajaran PJOK Materi Bola Besar dan Kecil Kelas VII Semester Genap. Tesis tidak diterbitkan. Universitas Negeri Malang, Malang.

Frey, B. B., Schmitt, V. L., \& Allen, J. P. (2012). Defining Authentic Classroom Assessment. Practical Assessment, Research \& Evaluation, $17(2), 1-18$.

Grainger, P., \& Weir, K. (2016). An Alternative Grading Tool for Enhancing Assessment Practice and Quality Assurance in Higher Education. Innovations in Education and Teaching International, 53(1), 73-83. https://doi.org/10.1080/14703297.2015.1022200

Harrison, A. G., Butt, K., \& Armstrong, I. (2019). Comparing Age- and Grade-Based Norms on the Woodcock-Johnson III Normative Update. Educational and Psychological Measurement, 1-20. https://doi.org/10.1177/0013164419834607

Juniarta, A. T., \& Winarno, M. E. (2016). Pengembangan Instrumen Penilaian Pengetahuan Mata Pelajaran Pendidikan Jasmani Olahraga dan Kesehatan (PJOK) Kelas XI Semester Gasal. Jurnal Pendidikan: Teori, Penelitian, dan Pengembangan, 1(8), 1659-1664.

Kanca, I. N. (2017). Pengembangan Profesionalisme Guru Penjasorkes. In Seminar Nasional Profesionalisme Tenaga Profesi PJOK, Pendidikan Olahraga Pascasarjana UM (pp. 1-14). https://doi.org/10.1007/s10531-008-9459-4

Karadeniz, M., Baran, T., Gökçek, T., \& Güç, F. (2015). Contextual Examination of the Turkish Middle School Mathematics Teachers' Exam Questions. Proceeding of the British Society for Research into Learning Mathematics, 35(2), 90-95.

Kastina, Z. V. K., \& Sujianto. (2017). Implementasi Sistem Penilaian dalam Kurikulum 2013 di SMA Negeri 2 Pekanbaru. JOM FISIP, 4(1), 1-15.

Kim, I., Lee, Y. S., Ward, P., \& Li, W. (2015). A Critical Examination of Movement Content Knowledge Courses in Physical Education Teacher Education Programs. Journal of Teaching in Physical Education, 34(1), 59-75. https://doi.org/10.1123/jtpe.2013-0166

Kirk, M. F. (2013). Using Portfolios to Enhance Student Learning \& Assessment. Journal of Physical Education, Recreation \& Dance, 68(7), 29-33. https://doi.org/10.1080/07303084.1997.10604980

Komarudin. (2016). Penilaian Hasil Belajar Pendidikan Jasmani dan Olahraga. Bandung: Remaja Rosdakarya.

Kunandar. (2013). Penilaian Autentik (Penilaian Hasil Belajar Peserta Didik Berdasarkan Kurikulum 2013). Jakarta: PT RajaGrafindo Persada.

Larasati, D. A., Hanafi, I., \& Hayat, A. (2013). Implementasi Sistem Manajemen Mutu Berbasis ISO 9001:2008 Dalam Lembaga Pendidikan (Studi pada SMAN 5 Malang). Jurnal Administrasi Publik (JAP), 1(1), 38-46.

Lester, J. (2015). Using Technology for Alternative Assessment in Health Education. Journal of Physical Education, Recreation \& Dance, 86(9), 50-52. https://doi.org/10.1080/07303084.2015.1086611

Logan, S. W., Barnett, L. M., Goodway, J. D., \& Stodden, D. F. (2017). Comparison of Performance on Process- and ProductOriented Assessments of Fundamental Motor Skills Across Childhood. Journal of Sports Sciences, 35(7), 634-641. https://doi.org/10.1080/02640414.2016.1183803

Logan, S. W., Robinson, L. E., Rudisill, M. E., Wadsworth, D. D., \& Morera, M. (2014). The Comparison of School-Age Children's Performance on Two Motor Assessments: The Test of Gross Motor Development and the Movement Assessment Battery for Children. Physical Education and Sport Pedagogy, 19(1), 48-59. https://doi.org/10.1080/17408989.2012.726979

López-Pastor, V. M., Kirk, D., Lorente-Catalán, E., MacPhail, A., \& Macdonald, D. (2013). Alternative Assessment in Physical Education: A Review of International Literature. Sport, Education, and Society, 18(1), 57-76. https://doi.org/10.1080/13573322.2012.713860

Metzler, M. (2011). Instructional Models for Physical Education. New York: Routledge.

Muryadi, A. D. (2017). Model Evaluasi Program dalam Penelitian Evaluasi. Jurnal Ilmiah PENJAS, 3(1), 1-15.

Nordrum, L., Evans, K., \& Gustafsson, M. (2013). Comparing Student Learning Experiences of in-Text Commentary and Rubric-Articulated Feedback: Strategies for Formative Assessment. Assessment \& Evaluation in Higher Education, 38(8), 919-940. https://doi.org/10.1080/02602938.2012.758229

Noviana, \& Kartowagiran, B. (2015). Evaluasi Implementasi Penilaian Otentik Pembelajaran Bahasa Indonesia pada Kurikulum 2013 di SMA. Jurnal Evaluasi Pendidikan, 3(2), 157-166.

Paturusi, A. (2012). Manajemen Pendidikan Jasmani dan Olahraga. Jakarta: Rineka Cipta. 
Poth, C., Lamarche, M. K., Yapp, A., Sulla, E., \& Chisamore, C. (2014). Towards a Definition of Evaluation within the Canadian Context: Who Knew This Would Be So Difficult? Canadian Journal of Program Evaluation / La Revue Canadienne d'évaluation de Programme, 29(1), 87-103. https://doi.org/10.3138/cjpe.29.1.87

Pratiwi, P. H., Hidayah, N., \& Martiana, A. (2017). Pengembangan Modul Matakuliah Penilaian Pembelajaran Sosiologi Berorientasi HOTS. Cakrawala Pendidikan, 36(2), 201-209.

Raharjo, S. B. (2012). Evaluasi Trend Kualitas Pendidikan di Indonesia. Jurnal Penelitian dan Evaluasi Pendidikan, 16(2), 511-532.

Reid, A. (2013). Physical Education, Cognition, and Agency. Educational Philosophy and Theory, 45(9), 921-933. https://doi.org/10.1080/00131857.2013.785357

Rind, I. A., \& Mari, M. A. (2019). Analysing the Impact of External Examination on Teaching and Learning of English at the Secondary Level Education. Cogent Education, 6(1), 1-14. https://doi.org/10.1080/2331186X.2019.1574947

Salimin, N., Jani, J., Shahril, M. I., \& Elumalai, G. (2015). Validity and Reliability of Comprehensive Assessment Instruments for Handball and Badminton Games in Physical Education. Asian Social Science, 11(23), 12-21. https://doi.org/10.5539/ass.v11n23p12

Schincariol, L. M., \& Radford, K. W. (2013). Checklists and Rubrics: An Alternative Form of Assessment in a University Volleyball Activity Course. Journal of Physical Education, Recreation \& Dance, 69(1), 25-32. https://doi.org/10.1080/07303084.1998.10605043

Smiley, W., \& Anderson, R. (2011). Measuring Students' Cognitive Engagement on Assessment Tests: A Confirmatory Factor Analysis of the Short Form of the Cognitive Engagement Scale. Research \& Practice in Assessment, 6(1), 17-28.

Sudijono, A. (2008). Pengantar Statistik Pendidikan. Jakarta: PT Raja Grafindo Persada.

Sugiyono. (2015). Metode Penelitian Pendidikan (Kuantitatif, Kualitatif dan R\&D). Bandung: Alphabeta.

Suherman, A. (2014). Implementasi Kurikulum Baru Tahun 2013 Mata Pelajaran Pendidikan Jasmani (Studi Deskriptif Kualitatif pada SDN Cilengkrang). Mimbar Sekolah Dasar, 1(1), 71-76.

Sukardi. (2011). Evaluasi Pendidikan Prinsip \& Operasionalnya. Jakarta: Bumi Aksara.

Supriyono. (2013). Evaluasi Program untuk Pendidikan dan Pelatihan. Malang: FIP UM.

Tim Direktorat Pembinaan SMP. (2017). Panduan Penilaian oleh Pendidik dan Satuan Pendidikan Sekolah Menengah Pertama. Retrieved March 15, 2018, from http://ditpsmp.kemdikbud.go.id/erapor/file/Panduan-Penilaian SMP-Revisi-2017.pdf

Van der Kleij, F. M., Vermeulen, J. A., Schildkamp, K., \& Eggen, T. J. H. M. (2015). Integrating Data-Based Decision Making, Assessment for Learning and Diagnostic Testing in Formative Assessment. Assessment in Education: Principles, Policy \& Practice, 22(3), 324-343. https://doi.org/10.1080/0969594X.2014.999024

Widoyoko, S. E. P. (2013). Evaluasi Program Pembelajaran: Panduan Praktis bagi Pendidik dan Calon Pendidik. Yogyakarta: Pustaka Pelajar.

Wijayanti, A. (2014). Pengembangan Autentic Assesment Berbasis Proyek dengan Pendekatan Saintifik untuk Meningkatkan Keterampilan Berpikir Ilmiah Mahasiswa. Jurnal Pendidikan IPA Indonesia, 3(2), 102-108. https://doi.org/10.15294/jpii.v3i2.3107

Winarno, M. E. (2013). Metodologi Penelitian dalam Pendidikan Jasmani. Malang: Universitas Negeri Malang.

Winarno, M. E. (2014). Evaluasi Hasil Belajar Pendidikan Jasmani Olahraga dan Kesehatan. Malang: Universitas Negeri Malang.

Winarno, M. E., Yudasmara, D. S., Taufik, \& Fadhli, N. R. (2019). Identification of High School Physical Education Teacher Assessment Model. In Advances in Health Science Research (AHSR) (Vol. 7, pp. 115-119).

Yli-Piipari, S. (2014). Physical Education Curriculum Reform in Finland. Quest, 66(4), 468-484. https://doi.org/10.1080/00336297.2014.948688

Yunus, M., \& Retnowati, T. H. (2014). Evaluasi Pelaksanaan Penilaian Kelas pada Mata Pelajaran Matematika SMP Negeri di Kabupaten Lombok Tengah. Jurnal Evaluasi Pendidikan, 2(2), 172-180.

Zhang, G., Zeller, N., Griffith, R., Metcalf, D., Williams, J., Shea, C., \& Misulis, K. (2011). Using the CIPP Evaluation Model as a Comprehensive Framework to Guide the Planning, Implementation, and Assessment of Service-Learning Programs. Journal of Higher Education Outreach and Engagement, 15(4), 57-84. 